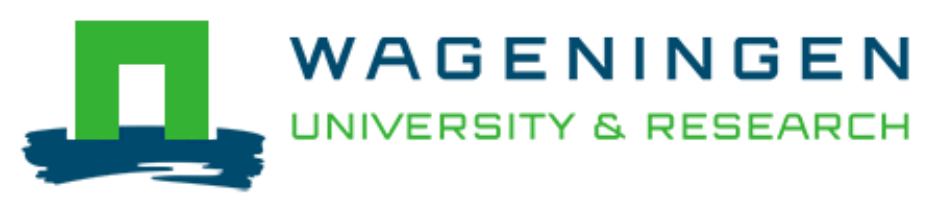

Global-scale impacts of nitrogen deposition on tree carbon sequestration in tropical, temperate, and boreal forests: A meta-analysis

Schulte-Uebbing, L., \& de Vries, W.

This article is made publically available in the institutional repository of Wageningen University and Research, under article 25fa of the Dutch Copyright Act, also known as the Amendment Taverne.

Article $25 \mathrm{fa}$ states that the author of a short scientific work funded either wholly or partially by Dutch public funds is entitled to make that work publicly available for no consideration following a reasonable period of time after the work was first published, provided that clear reference is made to the source of the first publication of the work.

For questions regarding the public availability of this article, please contact openscience.library@wur.nl.

Please cite this publication as follows:

Schulte-Uebbing, L., \& de Vries, W. (2018). Global-scale impacts of nitrogen deposition on tree carbon sequestration in tropical, temperate, and boreal forests: $A$ meta-analysis. Global Change Biology, 24(2), e416-e431.

https://doi.org/10.1111/gcb.13862 


\title{
Global-scale impacts of nitrogen deposition on tree carbon sequestration in tropical, temperate, and boreal forests: A meta-analysis
}

\author{
Lena Schulte-Uebbing $^{1}$ (D) | Wim de Vries ${ }^{1,2}$
}

\author{
${ }^{1}$ Environmental Systems Analysis Group, \\ Wageningen University and Research, \\ Wageningen, the Netherlands \\ ${ }^{2}$ Environmental Research (Alterra), \\ Wageningen University and Research, \\ Wageningen, the Netherlands

\section{Correspondence} \\ Lena Schulte-Uebbing, Environmental \\ Systems Analysis Group, Wageningen \\ University and Research, Wageningen, the \\ Netherlands. \\ Email: lena.schulte-uebbing@wur.nl \\ Funding information \\ VSNU Vereniging van Universiteiten; NWO, \\ Grant/Award Number: 022.003.009; SENSE \\ Research School
}

\begin{abstract}
Elevated nitrogen $(\mathrm{N})$ deposition may increase net primary productivity in $\mathrm{N}$-limited terrestrial ecosystems and thus enhance the terrestrial carbon (C) sink. To assess the magnitude of this $\mathrm{N}$-induced $\mathrm{C}$ sink, we performed a meta-analysis on data from forest fertilization experiments to estimate $\mathrm{N}$-induced $\mathrm{C}$ sequestration in aboveground tree woody biomass, a stable $\mathrm{C}$ pool with long turnover times. Our results show that boreal and temperate forests responded strongly to $\mathrm{N}$ addition and sequestered on average an additional 14 and $13 \mathrm{~kg} \mathrm{C}$ per $\mathrm{kg} \mathrm{N}$ in aboveground woody biomass, respectively. Tropical forests, however, did not respond significantly to $\mathrm{N}$ addition. The common hypothesis that tropical forests do not respond to $\mathrm{N}$ because they are phosphorus-limited could not be confirmed, as we found no significant response to phosphorus addition in tropical forests. Across climate zones, we found that young forests responded more strongly to $\mathrm{N}$ addition, which is important as many previous meta-analyses of $\mathrm{N}$ addition experiments rely heavily on data from experiments on seedlings and young trees. Furthermore, the $\mathrm{C}-\mathrm{N}$ response (defined as additional mass unit of $\mathrm{C}$ sequestered per additional mass unit of $\mathrm{N}$ addition) was affected by forest productivity, experimental $\mathrm{N}$ addition rate, and rate of ambient $\mathrm{N}$ deposition. The estimated $\mathrm{C}-\mathrm{N}$ responses from our meta-analysis were generally lower that those derived with stoichiometric scaling, dynamic global vegetation models, and forest growth inventories along $\mathrm{N}$ deposition gradients. We estimated $\mathrm{N}$-induced global $\mathrm{C}$ sequestration in tree aboveground woody biomass by multiplying the $\mathrm{C}-\mathrm{N}$ responses obtained from the meta-analysis with $\mathrm{N}$ deposition estimates per biome. We thus derived an $\mathrm{N}$-induced global $\mathrm{C}$ sink of about 177 (112-243) $\mathrm{Tg} \mathrm{C} /$ year in aboveground and belowground woody biomass, which would account for about $12 \%$ of the forest biomass C sink (1,400 Tg C/year).

\section{KEYWORDS}

$\mathrm{C}-\mathrm{N}$ response, fertilization experiments, forest carbon sink, meta-analysis, nitrogen deposition, woody biomass
\end{abstract}

\section{1 | INTRODUCTION}

The terrestrial biosphere takes up a substantial share of the carbon dioxide $\left(\mathrm{CO}_{2}\right)$ emitted by human activities, thereby mitigating climate change (Le Quéré et al., 2015; Myneni et al., 2001; Pan, Birdsey, et al., 2011). The amount of $\mathrm{CO}_{2}$ absorbed by the terrestrial biosphere is driven by, among others, changes in climate, land use, $\mathrm{CO}_{2}$ concentrations, and nitrogen ( $N$ ) deposition (Sitch et al., 2015). 
Atmospheric $\mathrm{N}$ deposition on forests has increased strongly over the last decades as a result of $\mathrm{N}$ use in agriculture and the emission of N compounds from combustion processes (Fowler et al., 2013; Galloway et al., 2008). The terrestrial carbon (C) and $\mathrm{N}$ cycles are closely linked: most terrestrial ecosystems are $\mathrm{N}$ limited, and increased $\mathrm{N}$ deposition thus stimulates biomass production and potentially terrestrial C sequestration (Bala, Devaraju, Chaturvedi, Caldeira, \& Nemani, 2013; LeBauer \& Treseder, 2008; Thomas, Canham, Weathers, \& Goodale, 2010; Zaehle, 2013). Only few global earth system models, however, include a representation of the $\mathrm{N}$ cycle and can assess impacts of $\mathrm{N}$ limitation and $\mathrm{N}$ deposition on the global $\mathrm{C}$ sink. The size of nitrogen's contribution to the global terrestrial $C$ sink is still debated, and estimates ranging from as low as $220 \mathrm{Tg} \mathrm{C} /$ year up to $740 \mathrm{Tg} \mathrm{C}$ /year have been published in recent years (Fleischer et al., 2015; Jain et al., 2009; de Vries, Du, \& Butterbach-Bahl, 2014; Zaehle, Ciais, Friend, \& Prieur, 2011).

Forests account for about $82 \%$ of the terrestrial C sink $(2.3 \mathrm{Gt}$ $\mathrm{C}$ /year of the total terrestrial sink of $2.8 \mathrm{Gt} \mathrm{C}$ /year for the period 2000-2009; Pan, Birdsey, et al., 2011; Le Quéré et al., 2015). At the global scale, forest soils and forest biomass both contain roughly equal amounts of carbon, but living biomass and dead wood accounts for about $75 \%$ of the carbon sequestered in forests (Ciais et al., 2008; Pan, Birdsey, et al., 2011). Even in regions where most carbon is contained in soils (i.e., where the soils is the largest carbon pool), biomass often still accounts for most of the additional sequestered carbon (i.e., biomass is the largest carbon sink). For example, for Europe, it is estimated that while tree biomass accounts for only
$35 \%$ of the forest carbon pool, $70 \%$ of the forest $C$ sink can be ascribed to $C$ sequestered in tree biomass, and $30 \%$ to $C$ sequestered in the soil (Janssens et al., 2003; Nabuurs, Schelhaas, \& Field, 2003). Naturally, this distribution varies between biomes (Luyssaert et al., 2007) and over time (Nabuurs et al., 2013).

The stimulating effect of $\mathrm{N}$ deposition on forest $\mathrm{C}$ sequestration can be estimated by multiplying total $\mathrm{N}$ deposition on forests with the $\mathrm{C}-\mathrm{N}$ response ratio of each forest ecosystem compartment. The $\mathrm{C}-\mathrm{N}$ response ratio (hereafter referred to as $\mathrm{C}-\mathrm{N}$ response) is defined as the additional mass unit of $\mathrm{C}$ sequestered per additional mass unit of $\mathrm{N}$ deposition. It is thus a measure of the efficiency with which forests use the additional $\mathrm{N}$. The size of the $\mathrm{N}$-induced $\mathrm{C}$ sink is mainly determined by $\mathrm{N}$-induced changes in $\mathrm{C}$ sequestration in pools with long turnover times: the tree $\mathrm{C}$ pool (wood) and the soil C pool (soil organic matter) (Luyssaert et al., 2007; Nabuurs et al., 2003; de Vries et al., 2014) (Figure 1). At decadal time scales (not accounting for large disturbances such as forest fires or harvest), $\mathrm{N}$ induced $C$ sequestration in the tree $C$ pool is determined by additional aboveground and belowground woody biomass production (stem, branches, and coarse roots). Nitrogen-induced $C$ sequestration in the soil $C$ pool is determined by inputs from additional aboveground and belowground litter production (leaves and fine roots), and losses from soil respiration (Figure 1). The Net Ecosystem Production (NEP) is defined as the sum of the tree $C$ pool and the soil $C$ pool and thus reflects the total amount of $C$ sequestered in an undisturbed forest ecosystem. The Net Biome Production (NBP) is defined as NEP minus $C$ losses through disturbances such as harvest

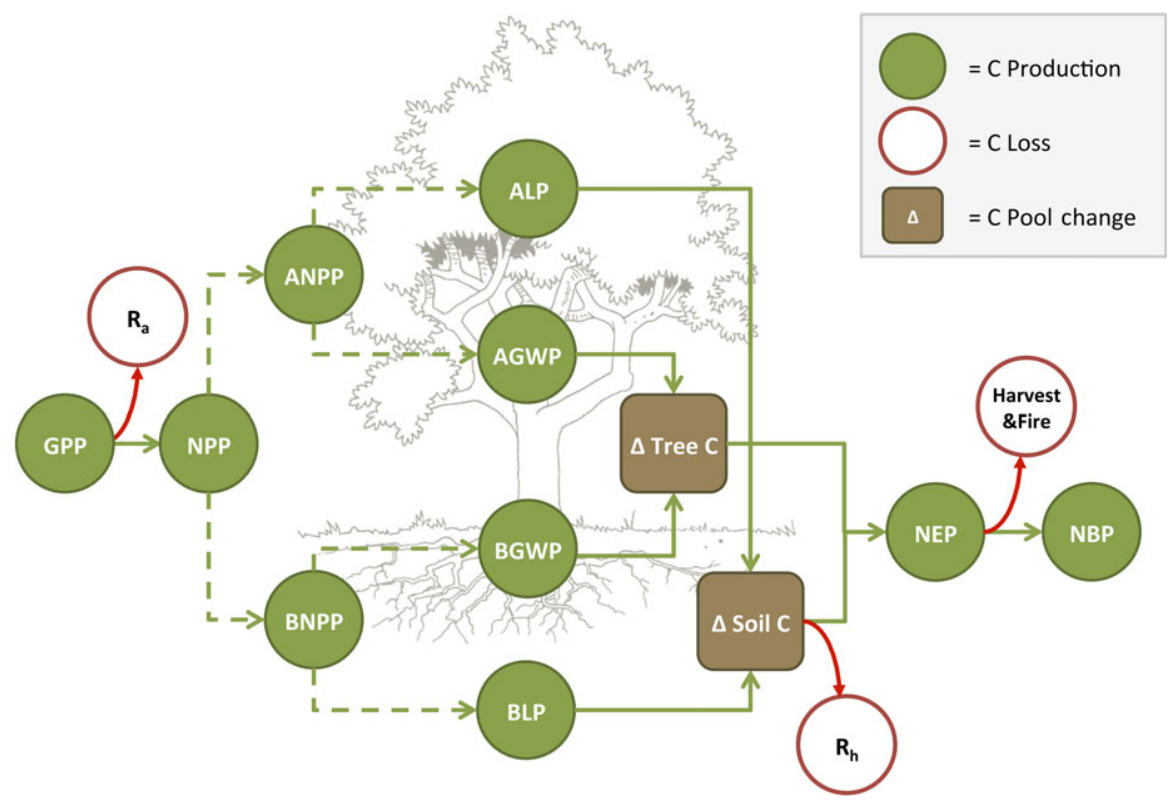

FIGURE 1 Conceptualization of the allocation of carbon assimilated through gross primary production (GPP) to the tree and the soil forest carbon pools. All circles and squares represent carbon fluxes (e.g., in g C/year). Net primary production (NPP) is GPP minus autotrophic (plant) respiration (Ra). NPP can be split up in aboveground NPP (ANPP) and belowground NPP (BNPP). Both ANPP and BNPP can be split up in a litter component (aboveground litter production (ALP) = leaves, belowground litter production (BLP) = fine roots), and a woody component (aboveground woody biomass production (AGWP) = stem and branches; belowground woody biomass production (BGWP) $=$ coarse roots). Together, AGWP and BGWP form the inputs to the tree carbon pool (Tree C). ALP and BLP form inputs to the soil carbon pool (Soil C), from which carbon is lost through heterotrophic respiration (Rh). Based on de Vries et al., 2014 [Color figure can be viewed at wileyonlinelibrary.com] 
and fires and thus reflects long-term net $C$ sequestration in the tree and soil pools. In this study, we focus on the tree $\mathrm{C}$ pool and how it responds to $\mathrm{N}$ addition.

The forest $\mathrm{C}-\mathrm{N}$ response, sometimes also referred to as $\mathrm{N}$ use efficiency, has been estimated by several approaches, each with its own strength and weaknesses. A relatively simple approach to estimate the $\mathrm{C}-\mathrm{N}$ response is stoichiometric scaling. In this approach, an estimate of the fraction of deposited $\mathrm{N}$ retained in the forest ecosystem (retention fraction) is multiplied with $\mathrm{N}$ allocation fractions and C: $\mathrm{N}$ ratios of each ecosystem compartment (e.g., Nadelhoffer et al., 1999; de Vries et al., 2014). The approach thus can account for variations in $\mathrm{N}$ retention, $\mathrm{N}$ allocation, and $\mathrm{C}: \mathrm{N}$ ratios between ecosystems, but relies on accurate estimates of these parameters, which are not always available at the global scale. Also, the stoichiometric scaling approach assumes that $\mathrm{N}$ retention and allocation fractions and $\mathrm{C}: \mathrm{N}$ ratios remain constant while these parameters might change over time under increasing levels of $\mathrm{N}$ deposition. Dynamic global vegetation models (DGVMs) have also been used to estimate $\mathrm{C}-\mathrm{N}$ responses (e.g., Fleischer et al., 2015; Jain et al., 2009; Zaehle et al., 2011). The advantage of these models is that they can account for spatial and temporal variation in factors driving forest productivity (such as tree species, climate, $\mathrm{CO}_{2}$ concentration, or soil texture). However, models do not capture all relevant processes, such as soil biologic processes (Wieder et al., 2015) or limitations by other nutrients affecting $\mathrm{C}-\mathrm{N}$ responses. For example, hardly any of the current DGVMs include phosphorus (P) cycle dynamics, while $P$ limitation of the terrestrial $C$ sink can be important in the tropics and becomes increasingly important in regions with high $\mathrm{N}$ deposition rates (Braun, Thomas, Quiring, \& Flückiger, 2010; Peñuelas et al., 2013; Sitch et al., 2015). Finally, gradient studies assess $\mathrm{C}-\mathrm{N}$ responses using large datasets, for example from growth observations at forest monitoring plots or eddy correlation measurements, to correlate forest productivity changes to environmental variables, including $\mathrm{N}$ deposition (e.g., Fleischer et al., 2013; Laubhann, Sterba, Reinds, \& de Vries, 2009; Magnani et al., 2007; Solberg et al., 2009; Thomas et al., 2010; de Vries et al., 2008). The advantage of these studies is that they rely on actually observed changes and thus include all other factors affecting forest productivity. However, isolating the effect of $\mathrm{N}$ deposition is tricky as $\mathrm{N}$ deposition may covary with other environmental drivers such as climate and ozone exposure (Fleischer et al., 2013; Sutton et al., 2008).

Fertilization experiments are the most direct way to assess forest $\mathrm{C}-\mathrm{N}$ responses. In those experiments, $\mathrm{N}$ is added to an experimental forest plot and changes in ecosystem response parameters are measured over a period of time. Forest fertilization experiments have been conducted in many parts of the world and can provide powerful insights in the isolated effects of $N$ deposition on forest $C$ sequestration, and potential co-limitation by other nutrients, such as P (Vadeboncoeur, 2010). However, their results are only valid for the conditions at the specific location where the experiment has been performed. While some experiments show a strong stimulation of tree $\mathrm{C}$ sequestration resulting from $\mathrm{N}$ addition (e.g., Liu et al.,
2010; Tanner, Kapos, Freskos, Healey, \& Theobald, 1990), others find that $\mathrm{N}$ addition does not significantly affect tree $\mathrm{C}$ sequestration (e.g., Lovett, Arthur, Weathers, Fitzhugh, \& Templer, 2013).

Meta-analysis is a powerful tool to synthesize quantitative information from a large number of $\mathrm{N}$ addition experiments performed under different environmental and experimental conditions (Knorr, Frey, \& Curtis, 2005) and thus allows to derive more general statements on the forest $\mathrm{C}$ sink response to $\mathrm{N}$ deposition from fertilization experiments. Several meta-analyses have assessed $\mathrm{N}$ addition effects on forest $\mathrm{C}$ fluxes and pools (see Table S1 for an overview). However, several limitations impede using results of these meta-analyses for estimating forest $\mathrm{C}-\mathrm{N}$ responses and thus the global $\mathrm{N}$ induced forest $\mathrm{C}$ sink. The first limitation is that many meta-analyses assess the effect of $\mathrm{N}$ addition on $\mathrm{C}$ fluxes, and thus results from these studies cannot be used to assess effect of $\mathrm{N}$ addition on the forest $C$ pool, that is, the tree $C$ pool and soil $C$ pool. For example, many meta-analyses focus on $\mathrm{N}$ effects on aboveground or total net primary production (ANPP or NPP), and include observations of N addition effects on litter production, fine root production, and woody biomass production (LeBauer \& Treseder, 2008; Maynard et al., 2014; Tian, Wang, Sun, \& Niu, 2016; Vadeboncoeur, 2010; Xia \& Wan, 2008). Furthermore, several meta-analyses have focused on $\mathrm{N}$ addition effects on (components of) soil respiration (Janssens et al., 2010; Knorr et al., 2005; Liu \& Greaver, 2010; Lu et al., 2011; Zhou et al., 2014), but it is not possible to directly infer $\mathrm{N}$ addition effects on forest soil $C$ sequestration from these studies as these studies generally do not look at the net effect of $N$ on $C$ inputs (aboveground and belowground litter production) and losses.

A second limitation of previous meta-analyses is that nearly all of them report response ratios (e.g., a $30 \%$ productivity increase resulting from $\mathrm{N}$ addition) instead of absolute responses (e.g., $\mathrm{kg} \mathrm{C}$ $\left.\mathrm{ha}^{-1} \mathrm{yr}^{-1}\right)$. This is true for several studies that have focused on impacts of $\mathrm{N}$ addition on aboveground woody biomass production (AGWP) (Newton \& Amponsah, 2006), tree C pool changes (Janssens et al., 2010), and soil C pool changes (Janssens et al., 2010; Lu et al., 2011; Nave, Vance, Swanston, \& Curtis, 2009). Using relative responses (ratios) as effect size in meta-analyses has the advantage that observations of fluxes of different magnitudes (e.g., changes in litter production of tree seedlings in the order of tens of $\mathrm{kg} \mathrm{C}$ $\mathrm{ha}^{-1} \mathrm{yr}^{-1}$ and changes in total biomass production in a mature trop-

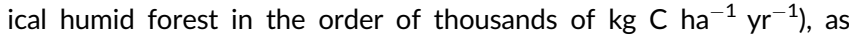
well as observations of responses measured in different units (e.g., stem diameter increment in $\mathrm{cm}$ per year and fine root production in $\mathrm{g} \mathrm{C} \mathrm{m}^{-2} \mathrm{yr}^{-1}$ ) can be grouped, as all responses are normalized to \% increase. However, as those meta-analyses neither report absolute responses nor give information on sensitivity of the response parameters to the amount of $\mathrm{N}$ added (i.e., \% NPP increase or $\mathrm{kg} \mathrm{C}$ sequestered per $\mathrm{kg} N$ added), their results cannot be used to estimate $\mathrm{C}-\mathrm{N}$ responses and thus the global $\mathrm{N}$-induced forest $\mathrm{C}$ sink. The few meta-analyses that report absolute $\mathrm{C}$ pool changes per $\mathrm{kg}$ $\mathrm{N}$ addition are limited to certain regions or based on a limited amount of studies. For example, Liu and Greaver (2009) estimated that forests sequester $24.5 \pm 8.7 \mathrm{~kg} \mathrm{C}$ per $\mathrm{kg} \mathrm{N}$ in tree biomass 
and soil, but their meta-analysis is based on only nine experimental studies in the US and includes observations of $\mathrm{N}$-induced changes in $\mathrm{C}$ fluxes to forest compartments with both short and long turnover times.

Another limitation of previous meta-analyses is that they hardly ever consider the effect of stand age on $\mathrm{N}$-induced changes in $\mathrm{C}$ fluxes. This is especially important as most published $\mathrm{N}$ fertilization experiments are performed on seedlings or very young trees, which can be assumed to respond more strongly to $\mathrm{N}$ due to lower $\mathrm{N}$ recycling rates and high $\mathrm{N}$ requirements per unit of biomass production (Sun et al., 2016). The only meta-analysis on $\mathrm{N}$ addition effects on forests that assessed the influence of stand age did indeed find a decrease in $\mathrm{N}$ response with increasing stand age (Vadeboncoeur, 2010) although the effect was not significant when including other factors in a multiple regression. A global-scale meta-analysis of the effect of $\mathrm{N}$ addition on $\mathrm{C}$ sequestration in woody biomass and the factors affecting this response, which is crucial for predicting the long-term response of the terrestrial $C$ sink based on results from forest fertilization experiments, is currently lacking.

While $\mathrm{N}$ is generally assumed to be the most limiting nutrient in most forest ecosystems (LeBauer \& Treseder, 2008; Vitousek et al., 1997), forests also require other elements for growth, such as $P$. High levels of $\mathrm{N}$ deposition over the last decades have not been matched by equal increases in $\mathrm{P}$ inputs, which has led to nutritional imbalances that ultimately might limit forest growth (Braun et al., 2010; Jonard et al., 2015; Peñuelas et al., 2013). Growth enhancement following $\mathrm{N}$ additions has been shown to increase $\mathrm{P}$ demand and decrease plant $P$ concentrations and $\mathrm{N}: \mathrm{P}$ ratios $(\mathrm{Li}, \mathrm{Niu}, \& \mathrm{Yu}$, 2016). A global meta-analysis of nutrient limitations in terrestrial, freshwater, and marine systems found strong evidence for co-limitation by $\mathrm{N}$ and $\mathrm{P}$ in all ecosystems (stronger response to $\mathrm{N}$ and $\mathrm{P}$ addition than to either one of these nutrients applied in isolation) (Elser et al., 2007), while a meta-analysis in northern hardwood forests found some evidence for co-limitation by $\mathrm{P}$ and calcium (Vadeboncoeur, 2010). In general, tropical forests are considered to be less responsive to $\mathrm{N}$ addition, as their old and weathered soils are thought to cause P limitation (Vitousek, Walker, Whiteaker, \& Matson, 1993).

In this paper, we present for the first time a meta-analysis of the effects of $\mathrm{N}$ and $\mathrm{P}$ addition on $\mathrm{C}$ sequestration in tree woody biomass in boreal, temperate, and tropical forests and assess factors affecting the variation in this effect. To test whether $P$ limitation can explain a lack of response to $\mathrm{N}$ addition in tropical forests (due to inherent $\mathrm{P}$ limitation) and in temperate and boreal forests (due to high $\mathrm{N}$ inputs), we also included experiments that assess $\mathrm{P}$ addition effects on tree woody biomass. Our major aim is to answer the following questions: (i) How does woody biomass production respond to $\mathrm{N}$ and $\mathrm{P}$ addition (both absolute response per unit of $\mathrm{N}$ or $\mathrm{P}$ addition and relative response)? (ii) How is the $\mathrm{C}-\mathrm{N}$ (or $\mathrm{C}-\mathrm{P}$ ) affected by stand characteristics (biome, forest net primary production (NPP), stand age, ambient $\mathrm{N}$ deposition) and experimental factors ( $\mathrm{N}$ or $\mathrm{P}$ addition level, form of $\mathrm{N}$ fertilizer)? and (iii) What is the contribution of $\mathrm{N}$ deposition to the global forest $\mathrm{C}$ sink?

\section{MATERIALS AND METHODS}

Meta-analysis is a method that quantitatively synthesizes results from many studies (Hedges, Gurevitch, \& Curtis, 1999). We followed the steps for meta-analysis described in Borenstein, Hedges, Higgins, and Rothstein (2009).

\subsection{Identification of literature, data selection, and data extraction}

An initial search in Scopus using a specific search string (see Table S2) led to 2115 results. From these initial search results, we selected publications that met the following criteria: (i) the experiment was performed on natural forests or forest plantations older than 10 years at the start of the experiment, (ii) the experiment included a control treatment, (iii) the publication reported aboveground or belowground woody biomass production (AGWP or BGWP) in $\mathrm{kg} \mathrm{Cha}^{-1} \mathrm{yr}^{-1}$, or a response that could be used to estimate AGWP or BGWP in $\mathrm{kg} \mathrm{Cha}^{-1} \mathrm{yr}^{-1}$, (iv) the publication reported a measure of variance of the response, ( $v$ ) the response variables were measured for at least 1 year after the first fertilization, and (vi) response variables were measured on plants that represent $90 \%$ or more of ecosystem biomass. We identified 25 publications containing 70 observations for $\mathrm{N}$ addition experiments and nine publications containing 28 observations for $\mathrm{P}$ addition experiments for use in our meta-analysis. As hardly any of the studies reported BGWP, we restricted our analysis to AGWP.

Data on woody biomass increment in the fertilized and control plots were extracted from the selected publications, either directly from tables and/or text or from figures using Plot Digitizer 2.6.6 (http://plotdigitizer.sourceforge.net). If required data were not reported in the publication, we e-mailed authors and asked them to provide us with additional data.

Several publications did not provide data on woody biomass production directly, but reported data that could be used to estimate it. If publications provided data on volumetric increments (e.g., $\mathrm{m}^{3} \mathrm{ha}^{-1} \mathrm{yr}^{-1}$ ), we multiplied those values with species-specific wood densities obtained from a global wood density database (http:// db.worldagroforestry.org//wd) and a C content of $50 \%$ to calculate AGWP in $\mathrm{kg} \mathrm{C}^{-1}$. If publications provided data on AGWP at tree level, we multiplied those values with plot-specific tree densities to obtain a per-area estimate.

If a publication reported data for several treatments (e.g., several levels of $\mathrm{N}$ addition) or for several study sites (e.g., several sites along an elevation gradient), those treatments were included as independent observations (in accordance with other meta-analyses, see for example Zhou et al. (2014)). If data on woody biomass increment from several years were reported, we calculated the average annual response over the longest period for which data were available.

For each observation, we included additional information on characteristics of the experimental plot (latitude and longitude, tree species, age) and the experiment ( $\mathrm{N}$ addition level, experimental duration, form of $\mathrm{N}$ fertilizer, etc.). Table S3 provides the additional 
information on the experimental sites (including country, location, forest type, etc.) while Tables S4 and S5 provide additional information on the experimental treatments for the $70 \mathrm{~N}$ addition experiments and $28 \mathrm{P}$ addition experiments, respectively. We classified each forest as either "young" (10-20 years), "intermediate" (2050 years), or "old" (>50 years), based on information on stand age provided in the publication. If stand age was not given, we classified a forest as belonging to one of the three age classes based on the available information (e.g., a "mature" forest was considered old). Information on background $\mathrm{N}$ deposition was assessed at each plot by an overlay with $\mathrm{NHx}$ and $\mathrm{NOx}$ deposition simulated with the TM5 atmospheric model on a $1^{\circ} \times 1^{\circ}$ grid for the year 2000 (Dentener et al., 2006).

Each experimental location was categorized as either "tropical and subtropical forest," "temperate forest," or "boreal forest" by overlaying coordinates of experimental plots with a map of terrestrial ecoregions (Olson et al., 2001; see Fig. S1). For more information on classification of ecoregions, see Appendix S1.

\section{2 | Meta-analysis}

For each individual observation, we calculated three different effect sizes and their variances (see (Hedges et al., 1999; Borenstein et al., 2009). For simplicity, we refer to the effects of $\mathrm{N}$ addition in the following only; P addition effects were calculated in exactly the same way.

(1) The absolute effect of $\mathrm{N}$ addition (AE) as:

$$
\mathrm{AE}=\bar{X}_{\mathrm{N}}-\bar{X}_{\mathrm{C}}
$$

where $X_{N}$ and $X_{C}$ are the mean aboveground woody biomass $C$ increments for the $\mathrm{N}$ addition and control plot, respectively (in g $\mathrm{C}$ $\mathrm{m}^{-2} \mathrm{yr}^{-1}$ ), and its variance as:

$$
\begin{gathered}
V_{\mathrm{AE}}=\frac{n_{\mathrm{N}}+n_{\mathrm{C}}}{n_{\mathrm{N}} * n_{\mathrm{C}}} * S_{\text {pooled }}^{2} \\
S_{\text {pooled }}=\sqrt{\frac{\left(n_{\mathrm{N}}-1\right) s_{\mathrm{N}}^{2}+\left(\mathrm{n}_{\mathrm{C}}-1\right) s_{\mathrm{C}}^{2}}{n_{\mathrm{N}}+n_{\mathrm{C}}-2}},
\end{gathered}
$$

where $n_{N}$ and $n_{C}$ are the number of replicates for the $N$ addition and the control treatment, respectively, and $\mathrm{s}_{\mathrm{N}}$ and $\mathrm{s}_{\mathrm{C}}$ are the sample standard deviations for the $\mathrm{N}$ addition and the control treatment, respectively.

(2) The absolute sensitivity to $\mathrm{N}$ addition (AS) as:

$$
\mathrm{AS}=\frac{\left(\bar{X}_{\mathrm{N}}-\bar{X}_{\mathrm{C}}\right)}{\mathrm{N}_{\mathrm{add}}}
$$

where $\mathrm{N}_{\text {add }}$ is the average amount of $\mathrm{N}$ fertilizer addition over the experimental period in $\mathrm{kg} \mathrm{N} \mathrm{ha}{ }^{-1} \mathrm{yr}^{-1}$, calculated as the total amount of $\mathrm{N}$ added to the treated plots divided by the duration of the observation period, and its variance as:

$$
V_{\mathrm{AS}}=\frac{V_{\mathrm{AE}}}{N_{\mathrm{add}}}
$$

(3) The relative response to $\mathrm{N}$ addition, calculated as the log response ratio:

$$
\ln \_\mathrm{RR}=\ln \left(\frac{\bar{X}_{\mathrm{N}}}{\bar{X}_{\mathrm{C}}}\right)
$$

and its variance as:

$$
V_{\text {In } \_ \text {RR }}=S_{\text {pooled }}^{2}\left(\frac{1}{n_{N}\left(\bar{X}_{N}\right)^{2}}+\frac{1}{n_{C}\left(\bar{X}_{C}\right)^{2}}\right)
$$

Meta-analysis was performed in R 3.1.3 (R Core Team, 2015) with the METAFOR package (Viechtbauer, 2010). We fitted both random- and mixed-effects models using climate zone, productivity (NPP), stand age, $\mathrm{N}$ addition rate, source of $\mathrm{N}$ fertilizer, and ambient $\mathrm{N}$ deposition as moderators. As we did not have data on NPP for most plots, we used aboveground woody biomass production (AGWP) in the control plot as a proxy for NPP. The randomeffects model calculates the mean effect size as the weighted mean of individual effect sizes, using the inverse of the sum of the within-study variance (due to sampling error) and between-study variance (due to variation in experimental conditions) as weights (Borenstein et al., 2009). The Der Simonian and Laird method was used to calculate between-study variances. The $95 \%$ confidence interval for each mean effect size was calculated as the effect size \pm 1.96 times the standard error. The effect of $\mathrm{N}$ on woody biomass increment was considered significant if the $95 \%$ confidence Interval did not overlap with 1 (for the absolute effect and absolute sensitivity) or with 0 (for the response ratio).

\subsection{Estimation of the global $\mathrm{N}$-induced $\mathrm{C}$ sink}

To calculate global $\mathrm{C}$ sequestration in forests' woody biomass resulting from $\mathrm{N}$ deposition, we multiplied average $\mathrm{C}-\mathrm{N}$ responses of (sub-)tropical, temperate, and boreal forests with the amount of total ambient $\mathrm{N}\left(\mathrm{NH}_{\mathrm{x}}+\mathrm{NO}_{x}\right)$ deposition on these forest types. Total $\mathrm{N}$ deposition per forest biome was estimated by first overlaying a land cover map (GLC, 2003) with a map of terrestrial ecoregions (Olson et al., 2001) to obtain a global map of forest classified into (sub-)tropical, temperate, and boreal forests. We then made an overlay with gridded TM5 model estimates of total $\mathrm{NH}_{x}+\mathrm{NO}_{x}$ deposition for the year 2000 (Dentener et al., 2006) to estimate average $\mathrm{N}$ deposition rates per forest biome. For more information, see Appendix S1.

\section{3 | RESULTS}

\subsection{Effects of nitrogen addition on aboveground woody biomass production}

Across all studies, $\mathrm{N}$ addition significantly increased AGWP by about $11 \mathrm{~kg} \mathrm{C}$ per $\mathrm{kg} \mathrm{N}(\mathrm{p}<0.0001$, see Figure 2a). The effect of $\mathrm{N}$ 
addition on AGWP differed per climate zone. In boreal and temperature forests, average AGWP increased significantly by about 14 and $12 \mathrm{~kg}$ C per kg N, respectively. Contrarily, AGWP in tropical forests did not show a significant response to $N$ addition $(p=.6)$. The relative increase in AGWP in response to $\mathrm{N}$ addition showed a similar pattern, with $\mathrm{N}$ addition increasing AGWP in boreal and temperate forests by 20 and 17\%, respectively, while tropical forests showed a non-significant increase of $5 \%$ (Figure $2 b$ ).

$\mathrm{N}$ addition led to a significantly stronger relative increase in AGWP in forests with a lower productivity (24\%) than in forests with a higher productivity (7\%). The absolute sensitivity to $\mathrm{N}$ addition was also higher in low-productivity forests $(+11.9 \mathrm{~kg} \mathrm{C}$ per kg $\mathrm{N}$ ) than in high-productivity forests (5.8 $\mathrm{kg} \mathrm{C}$ per $\mathrm{kg} \mathrm{N}$ ), but here the difference was not significant ( $p=.07$ ).

Forest age had a strong effect on forests' absolute sensitivity to $\mathrm{N}$ addition, with AGWP in young forests (stand age $<20$ years) responding significantly stronger to $\mathrm{N}$ addition ( $19.7 \mathrm{~kg} \mathrm{C}$ per $\mathrm{kg} \mathrm{N}$ ) than AGWP in intermediate and old forests (6.5 and $4.4 \mathrm{~kg} \mathrm{C}$ per kg $\mathrm{N}$, respectively). This difference is also apparent in the relative sensitivity: $N$ addition increased AGWP in young forest stands by $27 \%$ versus 8 and $12 \%$ in intermediate and old forest stands, respectively (Figure 2b).

(a) $E$ (n)

Mean (all studies)

$11.3(70)$

Climate zone

Boreal

Temperate

Tropical

Productivity

$<3000$ kg C ha-1 year-1

$>3000$ kg C ha-1 year-1

Age

Young

Intermediate

Old

$\mathrm{N}$-addition rate

$<30 \mathrm{~kg} \mathrm{~N}$ ha-1 year-1

30-70 kg N ha-1 year-1

$>70$ kg N ha-1 year-1

N source

Urea

$\mathrm{NH} 4 \mathrm{NO} 3$

Ambient $\mathbf{N}$ deposition

$<5 \mathrm{~kg}$ ha-1 year-1

5-15 kg ha-1 year-1

$>15 \mathrm{~kg}$ ha-1 year-1

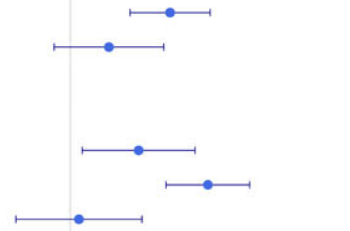

Nitrogen addition increased AGWP at all rates of $\mathrm{N}$ addition, but the efficiency with which additional $\mathrm{N}$ was converted to woody biomass decreased with increasing rates of $\mathrm{N}$ addition. While $\mathrm{N}$ addition rates below $30 \mathrm{~kg} / \mathrm{ha}$ increased AGWP by about $23 \mathrm{~kg} C$ per $\mathrm{kg} \mathrm{N}$, $\mathrm{N}$ addition rates between 30 and $70 \mathrm{~kg} \mathrm{~N}^{-1} \mathrm{yr}^{-1}$ only increased AGWP by $10 \mathrm{~kg} \mathrm{C}$ per $\mathrm{kg} \mathrm{N}$, and $\mathrm{N}$ addition rates above $70 \mathrm{~kg} \mathrm{~N}$ $\mathrm{ha}^{-1} \mathrm{yr}^{-1}$ increased AGWP by $5 \mathrm{~kg} \mathrm{C}$ per $\mathrm{kg} \mathrm{N}$ on average (Figure 2a). The relative increase in AGWP in response to $N$ addition, however, was equal for $\mathrm{N}$ addition rates below $30 \mathrm{~kg} \mathrm{~N}^{-1} \mathrm{yr}^{-1}$ and between 30 and $70 \mathrm{~kg} \mathrm{~N}$ ha $^{-1} \mathrm{yr}^{-1}$ (an increase in 20\%), while higher levels of $\mathrm{N}$ addition only led to a $10 \%$ increase in AGWP on average (Figure $2 \mathrm{~b}$ ).

Most of the experiments in the database used either ammonium nitrate $\left(\mathrm{NH}_{4} \mathrm{NO}_{3}\right)$ or urea as a source of $\mathrm{N}$. Fertilization with urea increased AGWP by about $11 \mathrm{~kg} \mathrm{C}$ per $\mathrm{kg} \mathrm{N}$ while fertilization with $\mathrm{NH}_{4} \mathrm{NO}_{3}$ increased AGWP by about $4 \mathrm{~kg} \mathrm{C}$ per $\mathrm{kg} \mathrm{N}$, but this difference was not significant $(p=.08$ ) (Figure 2). In terms of response ratios, there was hardly a difference.

Forest AGWP response to $\mathrm{N}$ addition was significantly lower at high rates of ambient $\mathrm{N}$ deposition $\left(>15 \mathrm{~kg} \mathrm{ha}^{-1} \mathrm{yr}^{-1}\right)$ than at ambient $\mathrm{N}$ deposition levels between 5 and $15 \mathrm{~kg} \mathrm{~N} \mathrm{ha}^{-1} \mathrm{yr}^{-1}$ (Figure 2). At even lower rates of ambient $\mathrm{N}$ deposition $\left(<5 \mathrm{~kg} \mathrm{~N} \mathrm{ha}^{-1} \mathrm{yr}^{-1}\right)$,

(b) $E(n)$

Mean (all studies)

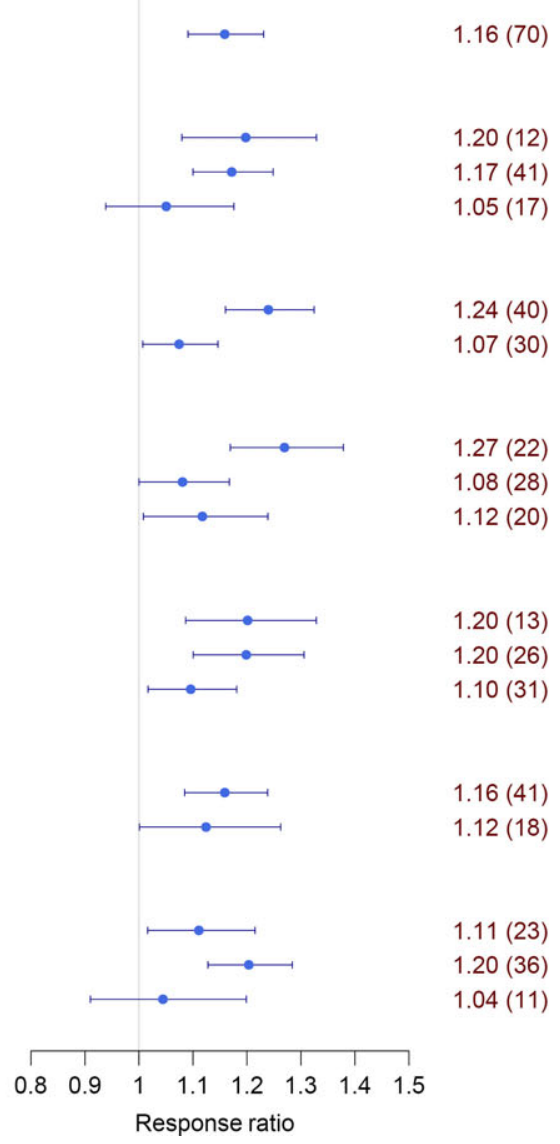

$1.16(70)$

Climate zone

14.1 (12) Boreal

12.7 (41) Temperate

1.3 (17) Tropical

Productivity

$11.9(40)<3000 \mathrm{~kg} \mathrm{C}$ ha-1 year-1

$5.8(30)>3000 \mathrm{~kg} \mathrm{C}$ ha-1 year -1

\section{Age}

19.7 (22) Young

6.5 (28) Intermediate

$4.4(20) \quad$ Old

$\mathrm{N}$-addition rate

$22.5(13) \quad<30 \mathrm{~kg} \mathrm{~N}$ ha-1 year-1

10.1 (26) $\quad 30-70 \mathrm{~kg} \mathrm{~N}$ ha-1 year-1

$4.6(31) \quad>70 \mathrm{~kg} \mathrm{~N}$ ha-1 year-1

\section{N source}

10.8 (41) Urea

4.2 (18) $\quad \mathrm{NH} 4 \mathrm{NO} 3$

\section{Ambient $\mathbf{N}$ deposition}

$7.4(23)<5$ kg ha-1 year-1

14.9 (36) $\quad 5-15 \mathrm{~kg}$ ha-1 year-1

0.9 (11) > $15 \mathrm{~kg}$ ha-1 year-1

FIGURE 2 Nitrogen addition effects on forest aboveground woody biomass increment, expressed as (a) the absolute sensitivity to nitrogen $(\mathrm{N})$ addition in $\mathrm{kg}$ carbon $(\mathrm{C})$ per $\mathrm{kg} \mathrm{N}$, and (b) the response ratio. Dots show mean effect sizes, bars are $95 \%$ confidence intervals. The last column shows mean effect sizes and the number of observations in parentheses [Color figure can be viewed at wileyonlinelibrary.com] 
forest AGWP response seemed to decline again; however, the difference with AGWP response at intermediate levels of $N$ deposition was not significant. The response ratio follows a pattern similar to that of the absolute sensitivity; however, differences between groups are not significant here.

\subsection{Effects of phosphorus addition on aboveground woody biomass production}

Across all studies, $\mathrm{P}$ addition did not significantly increase AGWP production ( $p=.1$, see Figure 3 a). The mean response for tropical forests was higher (6.7 $\mathrm{kg} \mathrm{C}$ per $\mathrm{kg} P$ ) than for temperate forests (1.6 kg C per kg P), but both responses were not significant. Similar to $\mathrm{N}$, the $\mathrm{C}-\mathrm{P}$ response, also denoted as $\mathrm{P}$ use efficiency, seems to decrease with increasing rates of $P$ addition (from $5.5 \mathrm{~kg} C$ per $\mathrm{kg} P$ at $\mathrm{P}$ addition levels below $50 \mathrm{~kg} \mathrm{P} \mathrm{ha}^{-1} \mathrm{yr}^{-1}$ to $1.9 \mathrm{~kg} \mathrm{C}$ per $\mathrm{kg} \mathrm{P}$ at $\mathrm{P}$ addition levels above $50 \mathrm{~kg} \mathrm{P} \mathrm{ha}{ }^{-1} \mathrm{yr}^{-1}$ ). However, again this difference was not significant.

The fact that tropical forests show no significant response to either $\mathrm{N}$ addition or $\mathrm{P}$ addition led to the question whether co-limitation by both nutrients could explain this lack of a response. We selected experiments from the database that included $\mathrm{N}, \mathrm{P}$, and $\mathrm{N}+\mathrm{P}$ (NP) treatments to test whether the effects of $\mathrm{N}$ and $\mathrm{P}$ are synergistic. In case of a synergistic effect, the effect of NP addition would be larger than the sum of the individual effects of $\mathrm{N}$ and $\mathrm{P}$ addition. Results are shown in Figure 4. Indeed, most sites seemed to be colimited by $\mathrm{N}$ and $\mathrm{P}$ as the response to NP addition was higher than the combined responses to $\mathrm{N}$ and $\mathrm{P}$ addition. However, three plots also showed antagonistic effects.

\section{3 | Global nitrogen-induced forest carbon sink}

Based on an overlay with a global land cover map and spatially explicit estimates of $\mathrm{N}$ deposition for the year 2000, we estimated a global N-induced C sequestration in AGWP of 148 (93-202) Tg C/year (Table 1). Temperate forests accounted for two-thirds of the $\mathrm{N}$ induced $\mathrm{C}$ sink (101 Tg C/year), due to both a high $\mathrm{C}-\mathrm{N}$ response and high levels of atmospheric $\mathrm{N}$ deposition (ca. $7.8 \mathrm{~kg} \mathrm{~N} \mathrm{ha}^{-1} \mathrm{yr}^{-1}$ ). Boreal and tropical forests together accounted for one-third of global $\mathrm{N}$-induced $\mathrm{C}$ sequestration (Table 1). Global $\mathrm{C}$ sequestration in tropical forests was limited by a very low (non-significant) $\mathrm{C}-\mathrm{N}$ response in aboveground woody biomass. $\mathrm{N}$-induced $\mathrm{C}$ sequestration in boreal forests was limited as $\mathrm{N}$ deposition levels in this region are relatively low (ca. $1.8 \mathrm{~kg} \mathrm{~N} \mathrm{ha}^{-1} \mathrm{yr}^{-1}$ ).

Our estimate of $\mathrm{N}$-induced $\mathrm{C}$ sequestration in woody biomass only includes aboveground woody biomass, as hardly any of the studies in our meta-analysis reported BGWP. The amount of $C$ allocated to coarse roots is typically $20 \%$ of the $C$ allocation to aboveground woody biomass, with little variation between biomes (Cleveland et al., 2013). If we assume that fertilization does not change biomass allocation fractions to tree compartments and thus the belowground woody biomass pool responds to $\mathrm{N}$ deposition in a similar manner (which is supported by several fertilization experiments, see e.g., livonen, Kaakinen, Jolkkonen, Vapaavuori, \& Linder, 2006), we can calculate total woody biomass $\mathrm{C}$ increment due to $\mathrm{N}$ deposition by multiplying the AGWP estimate by 1.2. Our estimate of the total global $\mathrm{N}$-induced $\mathrm{C}$ sink in woody biomass thus obtained is $177(112-243) \mathrm{Tg} C /$ year (see Table S6). This would account for about $12 \%$ of the forest biomass $C$ sink (1,400 Tg C/year according to Pan, Birdsey, et al., 2011).

\section{DISCUSSION}

\subsection{Limitations of the research}

While meta-analysis attempts to infer conclusions from individual experimental results to a larger population, there are several limitations in doing this. First of all, our database lacks geographical balance: while most forests are situated in boreal and tropical regions (FAO, 2016; see Table 1), by far the most observations in our database (41 out of 70) are from temperate forests (see Fig. S1). Another limitation in extrapolating results from our meta-analysis to global forests is that the $\mathrm{N}$ addition rates used in the experiments in our database are generally much higher (between 30 and $300 \mathrm{~kg} \mathrm{~N}$ $\mathrm{ha}^{-1} \mathrm{yr}^{-1}$ ) than atmospheric $\mathrm{N}$ addition rates that forests currently (a)

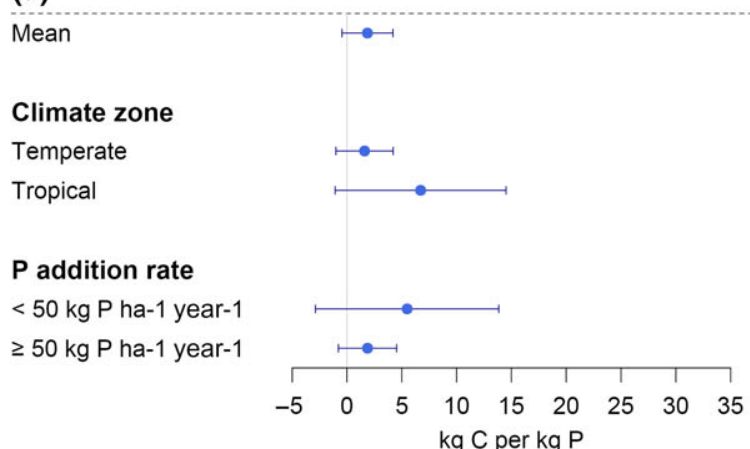

$E(n)$

$1.9(28)$

$1.6(18)$

$6.7(10)$

$5.5(8)$

$1.9(20)$ (b)

\section{Mean}

Climate zone

Temperate

Tropical

\section{$P$ addition rate}

$<50 \mathrm{~kg} \mathrm{P}$ ha-1 year-1

$\geq 50 \mathrm{~kg} \mathrm{P}$ ha-1 year-1
$E$ (n)

$1.05(28)$
1.04 (18)

$1.1(10)$

$1.08(8)$

$1.04(20)$

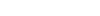

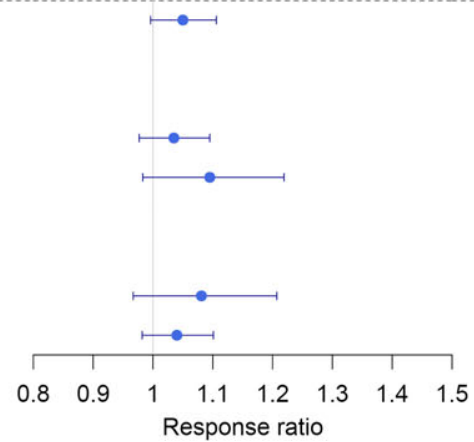

FIGURE 3 Phosphorus addition effects on forest aboveground woody biomass increment, expressed as (a) the absolute sensitivity to phosphorus $(\mathrm{P})$ addition in $\mathrm{kg}$ carbon $(\mathrm{C})$ per $\mathrm{kg} \mathrm{P}$ and (b) the response ratio. Dots show mean effect sizes, bars are $95 \%$ confidence intervals. The last column shows mean effect sizes and the number of observations in parentheses [Color figure can be viewed at wileyonlinelibrary.com] 
experience (between 2 and $35 \mathrm{~kg} \mathrm{~N} \mathrm{ha}^{-1} \mathrm{yr}^{-1}$ ). In addition, atmospheric $\mathrm{N}$ deposition occurs continuously throughout the year, while in the experiments fertilizers are applied every few months to years. It is likely to assume that experiments with high $\mathrm{N}$ addition rates and large time intervals (several years or more) between $\mathrm{N}$ applications underestimate the response to $\mathrm{N}$ addition, as with continuous low $\mathrm{N}$ addition plant $\mathrm{N}$ demand and supply are better matched. However, only very few studies were designed to mimic atmospheric $\mathrm{N}$ deposition by adding $\mathrm{N}$ at low rates during a long time period. Those studies, which have mostly been conducted in boreal forests, find $\mathrm{C}-\mathrm{N}$ responses between 16 and $25 \mathrm{~kg} \mathrm{C} \mathrm{kg} \mathrm{per} \mathrm{N}$, slightly higher than our estimate for boreal forests of $10.6-17.5 \mathrm{~kg} \mathrm{C}$ per kg N (see Table 1) (Gundale, From, Bach, \& Nordin, 2014; Högberg, Fan, Quist, Binkley, \& Tamm, 2006; Hyvönen et al., 2008; Magill et al., 2004; Pregitzer, Burton, Zak, \& Talhelm, 2008). Similarly,

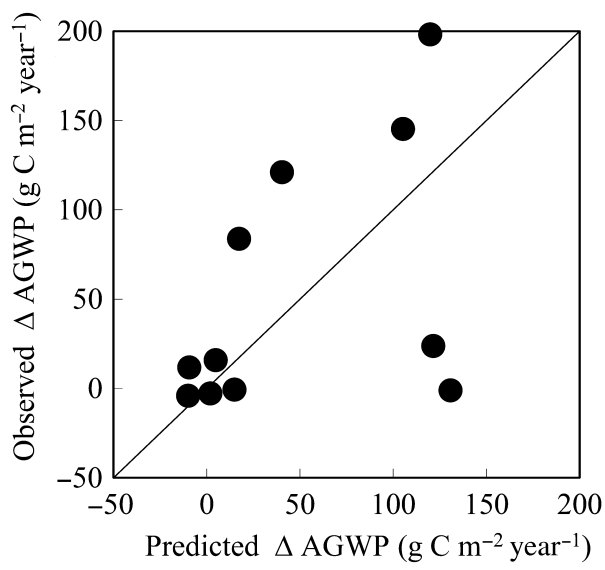

FIGURE 4 Observed absolute changes in aboveground woody biomass production (AGWP) in response to nitrogen (N) + phosphorus $(\mathrm{P})$ addition, and predicted AGWP response to NP addition, calculated as the sum of the individual response of AGWP to $\mathrm{N}$ and $\mathrm{P}$ addition. Dots below the 1:1 line indicate an antagonistic effect (the effect of NP addition is smaller than the sum of the individual effects of $\mathrm{N}$ and $\mathrm{P}$ addition), while dots on or close to the line indicate an additive effect (the effect of NP addition is equal to the sum of the individual effects of $\mathrm{N}$ and $\mathrm{P}$ addition) and dots above the line indicate synergistic effects (the effect of NP addition is larger than the sum of the individual effects of $\mathrm{N}$ and $\mathrm{P}$ addition) another meta-analysis found no significant effect of $\mathrm{N}$ addition frequency on ANPP response to $\mathrm{N}$ addition (Tian et al., 2016). Finally, about half of the forest plots in our database were planted forests, while globally, planted forests only account for $7 \%$ of the forest area (FAO, 2016).

In our analysis of the experimental data, we implicitly assume that everything in the experimental plots is equal, except for the added fertilizer. However, in some cases, the pre-treatment growth rate might have been different in fertilized and control plots. In these cases, the difference in woody biomass accumulation between the fertilized and control plots does not give an accurate indication of the effect of fertilizer addition. A comparison of the growth rate in fertilized plots after fertilization compared to before fertilization might be a better indicator, but these data were usually not available.

When determining the impact of nutrient additions on $\mathrm{C}$ sequestration in tree biomass, we are interested in the $C$ contained in the whole stand, rather than $C$ contained in individual trees. However, many studies are based on measurements of a number of sample trees. If tree mortality is not included, this can distort results. For example, Shryock, Littke, Ciol, Briggs, and Harrison (2014) found that while $\mathrm{N}$ fertilization led to a significant increase in the tree $\mathrm{C}$ pool (10\% increase on average), it did not lead to a significant increase in tree $\mathrm{C}$ sequestration at stand level because mortality was higher in fertilized trees. Shen, Moore, and Hatch (2001) also found that mortality in Douglas fir was about 1.4 and 2.1 times higher in stands fertilized with 224 and $448 \mathrm{~kg} \mathrm{~N}$ ha $^{-1} \mathrm{yr}^{-1}$, respectively, than in unfertilized plots. On the other hand, such $\mathrm{N}$ inputs are much higher than atmospheric $\mathrm{N}$ addition rates to forests, as mentioned above, and may thus have less relevance for the field situation.

\subsection{Factors affecting forest $\mathrm{C}$ response to $\mathrm{N}$ addition}

\subsection{1 $\mid$ Biome}

The decrease in forest $\mathrm{C}$ sequestration in response to $\mathrm{N}$ addition with latitude that we observe in our data is in line with the

TABLE 1 Summary effect sizes for $\mathrm{C}-\mathrm{N}$ responses per forest biome obtained from the meta-analysis (1), estimates of total $\mathrm{N}\left(\mathrm{NH}_{\mathrm{x}}+\mathrm{NO}_{\mathrm{x}}\right)$ deposition per forest biome (2), total forest area per forest biome (3), and the calculated nitrogen-induced carbon sink (4). Values shown are means; values in brackets are confidence intervals ( \pm 1 standard error)

\begin{tabular}{|c|c|c|c|c|}
\hline & 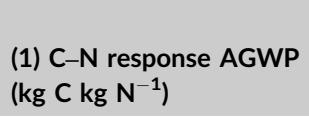 & $\begin{array}{l}\text { (2) Average } \mathrm{NH}_{\mathrm{x}}+\mathrm{NO}_{\mathrm{x}} \\
\text { deposition } \\
\left(\mathrm{kg} \mathrm{N} \mathrm{ha}^{-1} \mathrm{yr}^{-1}\right)\end{array}$ & $\begin{array}{l}\text { (3) Forest area } \\
\left(\text { ha } \times 10^{9}\right)\end{array}$ & $\begin{array}{l}\text { (4) } \mathrm{N} \text {-induced C sink } \\
\text { AGWP }=(1) *(2) *(3) \\
(\text { Tg C/year) }\end{array}$ \\
\hline Tropical forests $(n=17)$ & $1.3(-1.3-3.9)$ & 6.4 & 1.79 & $15(-15-44)$ \\
\hline Temperate forests $(n=41)$ & $12.7(10.6-14.9)$ & 7.8 & 1.02 & $101(84-119)$ \\
\hline Boreal forests $(n=12)$ & $14.1(10.6-17.5)$ & 1.8 & 1.21 & 32 (24-39) \\
\hline All $(n=70)$ & $11.3(8.7-13.9)$ & 5.4 & 4.02 & $148(93-202)$ \\
\hline
\end{tabular}

${ }^{a} \mathrm{~N}$ deposition estimates are based on an overlay of the GLC 2000 and the total deposition of $\mathrm{NH}_{\mathrm{x}}$ and $\mathrm{NO}_{\mathrm{x}}$ at $1 \times 1$ degree calculated with the TM5 model for the year 2000 (Dentener et al., 2006). Note that the $\mathrm{C}-\mathrm{N}$ response for "All" is the weighted mean response across all experiments, not an area-weighted mean of the $\mathrm{C}-\mathrm{N}$ responses per biome. 
common hypothesis that boreal forest respond most strongly to $\mathrm{N}$ addition because $\mathrm{N}$ mineralization is limited at low temperatures. Forests on tropical soils are generally assumed to be less responsive to $\mathrm{N}$ addition because they are mainly $\mathrm{P}$ limited. $\mathrm{N}$-rich tropical forests are often characterized by high rates of $\mathrm{N}$ cycling, a high soil $\mathrm{N}$ availability, and high rates of $\mathrm{N}$ losses, both by air emissions and leaching. Nitrate leaching is associated with leaching of aluminum and base cations and soil acidification (Fang et al., 2009; Lu, Mao, Gilliam, Luo, \& Mo, 2014). Nitrogen deposition can thus contribute to soil acidification in tropical ecosystems, thereby reducing rather than stimulate growth and carbon sequestration. Indeed, we did not find a significant response of woody biomass increment to $\mathrm{N}$ addition in tropical forests (neither for the response ratio nor for the $\mathrm{C}-\mathrm{N}$ response). This contradicts the results of LeBauer and Treseder (2008) who found a significant increase in NPP in response to $\mathrm{N}$ addition in tropical forests of $20 \%$, similar to the response that they found for temperate and boreal forests.

Comparing our estimates for $\mathrm{C}-\mathrm{N}$ responses for AGWP in different biomes to estimates obtained by stoichiometric scaling (de Vries et al., 2014) and the global dynamic vegetation model LPJ-GUESS (Fleischer et al., 2015), we find that estimates from our meta-analysis are generally lower (see Table 2). For tropical forests, our results for AGWP response are lower than the estimate from stoichiometric scaling (5.0 kg C per $\mathrm{kg} \mathrm{N}$ ), and much lower than the estimate for AGWP+BGWP from the DGVM (25.9 kg C per kg N). One reason for the much higher response found by the DGVM might be that the model lacks a representation of the $\mathrm{P}$ cycle, and also for tropical forests there are much fewer observations that can constrain the model (Fleischer et al., 2015).

For temperate forests, the $\mathrm{C}-\mathrm{N}$ response for AGWP estimated by the meta-analysis ( $12.7 \mathrm{~kg} \mathrm{C}$ per $\mathrm{kg} \mathrm{N}$ ) is very similar to the estimate for AGWP from stoichiometric scaling (14.4 kg C per $\mathrm{kg} \mathrm{N}$ ) and lower than the estimate for AGWP+BGWP from the DGVM (24.0 kg C per kg N). Our estimate is lower than that from a metaanalysis by Liu and Greaver (2009) that estimated a C-N response in of $24.5 \pm 8.7 \mathrm{~kg} \mathrm{C}$ per $\mathrm{kg} \mathrm{N}$ based on fertilization experiments in the US (mainly temperate forests). However, this analysis included $\mathrm{N}$-induced carbon sequestration in both the tree and the soil $\mathrm{C}$ pools. Assuming that the tree biomass pool accounts for about half of total $\mathrm{N}$-induced $\mathrm{C}$ sequestration (as supported by e.g. Janssens et al., 2010), their estimate can be considered similar to our results. A study using data from forest inventories in the northeastern and north-central United States found that tree $\mathrm{C}$ sequestration increased linearly over the observed range of $\mathrm{N}$ deposition and deduced an effect of 61 (51-82) $\mathrm{kg} C$ per $\mathrm{kg} \mathrm{N}$ (Thomas et al., 2010). Two studies in Europe, using similar methods, also found $\mathrm{C}-\mathrm{N}$ responses between 19 and $26 \mathrm{~kg} \mathrm{C}$ per kg N (Laubhann et al., 2009; Solberg et al., 2009). However, isolating the effect of $\mathrm{N}$ deposition in these empirical studies is tricky as it might covary with other environmental drivers such as climate and ozone exposure (Sutton et al., 2008; de Vries et al., 2008).

For boreal forests, the $\mathrm{C}-\mathrm{N}$ response for AGWP estimated by the meta-analysis (14.1 $\mathrm{kg} \mathrm{C}$ per $\mathrm{kg} \mathrm{N}$ ) is slightly lower than the estimate for AGWP+BGWP from the DGVM (17.5 kg C per kg N), while the estimate from stoichiometric scaling for AGWP is about $50 \%$ higher ( $21.3 \mathrm{~kg} \mathrm{C}$ per $\mathrm{kg} \mathrm{N}$ ). Our estimate is similar to a recent longterm fertilization experiment in a boreal forest by Gundale et al. (2014) who estimate the $\mathrm{C}-\mathrm{N}$ response of boreal forests (AGWP+BGWP) at $16 \mathrm{~kg} \mathrm{C}$ per $\mathrm{kg} \mathrm{N}$.

\subsection{2 | Productivity}

None of the previous meta-analysis that assessed $\mathrm{N}$ fertilization effects on forest growth response has assessed how the response to $\mathrm{N}$ addition is affected by the productivity of the forest site. This is an important omission as most previous meta-analyses have reported tree biomass response to $\mathrm{N}$ addition as relative responses (response ratios, see Table S1). However, a certain relative response to $\mathrm{N}$ addition in a highly productive forest means a much stronger stimulation of the forest $\mathrm{C}$ sink in absolute terms than the same response in a low-productivity forest. Our results showed that $\mathrm{N}$ induced relative AGWP increase was about three times higher in forests with a low productivity than in forests with a higher productivity $(24 \%$ vs. $7 \%)$. The absolute response to $N$ addition ( $-N$ response) was also higher in low-productivity forests although the difference was not significant. One possible explanation is that highly productive forests are less likely to be limited by N. For the response of soil respiration to $\mathrm{N}$ addition, a meta-analysis by Janssens et al. (2010) showed that the reduction of soil respiration is

TABLE 2 Comparison of C-N responses for tree woody biomass obtained by our meta-analysis and other approaches

\begin{tabular}{|c|c|c|c|c|c|}
\hline \multirow[b]{2}{*}{ Compartment } & \multirow{2}{*}{$\begin{array}{l}\text { Meta-analysis (this study) } \\
\text { AGWP }\end{array}$} & \multicolumn{3}{|c|}{ Stoichiometric scaling (de Vries et al., 2014) } & \multirow{2}{*}{$\begin{array}{l}\text { DGVM }^{\text {a }} \text { (Fleischer et al., 2015) } \\
\text { AGWP+ BGWP }\end{array}$} \\
\hline & & AGWP & BGWP & AGWP+ BGWP & \\
\hline Tropical forests & $1.3 \pm 2.6$ & $5.0 \pm 1.7$ & $1.1 \pm 0.3$ & $6.1 \pm 2.0$ & $25.9 \pm 10.8$ \\
\hline Boreal forests & $14.1 \pm 3.5$ & $21.3 \pm 4.3$ & $5.0 \pm 1.0$ & $26.3 \pm 5.3$ & $17.5 \pm 5.2$ \\
\hline All & $11.3 \pm 2.6$ & & & & $23.0 \pm 7.5$ \\
\hline
\end{tabular}

Values shown are means \pm 1 standard error. AGWP, aboveground woody biomass production; BGWP, belowground woody biomass production; DGVM, dynamic global vegetation model.

${ }^{a}$ Site-scale simulations calibrated with data from 68 forest FLUXNET sites. 
stronger at sites with a higher productivity (which means that $\mathrm{N}$ has a stronger effect on soil $C$ sequestration at sites with a higher productivity), probably because at less productive, $\mathrm{N}$-limited sites $\mathrm{N}$ immobilization is stronger and thus the effect of $\mathrm{N}$ on respiration is less pronounced.

\subsection{3 | Age}

The relevance of stand age for forest carbon flows has long been recognized (Pregitzer \& Euskirchen, 2004) and was confirmed by our results, as we found that AGWP in young forests responded more strongly to $\mathrm{N}$ addition than in older forests. The absolute sensitivity of AGWP to $\mathrm{N}$ addition was more than twice as high in young forests (stand age 10-20 years) than in forests 20 years or older. In young forest stands, high nutrient requirements for growth and higher dependence on external $\mathrm{N}$ inputs might exacerbate nutrient limitation (Sun et al., 2016), explaining the stronger response to $N$ addition in these stands. The only other meta-analysis on $\mathrm{N}$ addition effects on forests that assessed the influence of stand age also found a decrease in $\mathrm{N}$ response with increasing stand age (Vadeboncoeur, 2010). Most previous meta-analysis relies heavily on data from very young forest stands and/or seedlings. In our analysis, we attempted to reduce the bias by excluding experiments performed on forest stands younger than 10 years. This might explain why our biome-level responses are lower than those found in previous metaanalyses (see Table 3).

\subsection{4 $\mathrm{N}$ addition rate}

We found a strong decrease in $\mathrm{C}-\mathrm{N}$ response with increasing $\mathrm{N}$ inputs. These results confirm results from a recent meta-analysis by Tian et al. (2016) that investigated $N$ fertilization experiments with multiple levels of $\mathrm{N}$ addition and also found a sharp decrease in ANPP response to $N$ addition at $N$ addition levels above $40 \mathrm{~kg} \mathrm{~N}$ $\mathrm{ha}^{-1} \mathrm{yr}^{-1}$. At high levels of $\mathrm{N}$ addition, $\mathrm{N}$ leaching starts to increase and $\mathrm{N}$ retention starts to decrease (Templer et al., 2012). For example, an $\mathrm{N}$ fertilization experiment in Sweden showed that long-term addition of $34 \mathrm{~kg} \mathrm{~N} \mathrm{ha}^{-1} \mathrm{yr}^{-1}$ increased woody biomass increment in Norway spruce by $25 \mathrm{~kg} \mathrm{C}$ per $\mathrm{kg} \mathrm{N}$, while addition of $68 \mathrm{~kg} \mathrm{~N}$ $\mathrm{ha}^{-1} \mathrm{yr}^{-1}$ only led to an increase in $6 \mathrm{~kg} \mathrm{C}$ per $\mathrm{kg} \mathrm{N}$ and addition of $108 \mathrm{~kg} \mathrm{~N} \mathrm{ha}^{-1} \mathrm{yr}^{-1}$ led to no increase in woody biomass altogether
(Högberg et al., 2006). Data from eddy flux measurements at 68 sites across the globe found that the increase in photosynthetic capacity with increasing levels of $\mathrm{N}$ deposition levels off at an ambient $\mathrm{N}$ deposition of $8 \mathrm{~kg} \mathrm{~N} \mathrm{ha}^{-1} \mathrm{yr}^{-1}$ in evergreen needle-leaf forests (Fleischer et al., 2013).

For the relative AGWP response to $\mathrm{N}$ addition (response ratio), we also found a decrease in increasing level of $\mathrm{N}$ deposition. However, this decrease was not as clear as the decrease in the absolute sensitivity to $\mathrm{N}$ addition. Similarly, other meta-analyses that used the response ratio as effect size did not find a significant effect of $N$ addition level on forest ecosystem C content (Liu \& Greaver, 2009) or on NPP (Xia \& Wan, 2008).

\subsection{5 $\quad \mathrm{N}$ source}

AGWP response to $\mathrm{N}$ addition might vary between different $\mathrm{N}$ fertilizer types due to differences in $\mathrm{N}$ losses and related $\mathrm{N}$ availability in time and space to the plants. In line with previous meta-analyses (e.g., LeBauer \& Treseder, 2008; Liu \& Greaver, 2009; Vadeboncoeur, 2010), we did not find $N$ source to have a significant effect on biomass response (in our case, the absolute sensitivity or relative response of AGWP to $\mathrm{N}$ addition). The absolute sensitivity was slightly higher in experiments that used urea, but this effect was not significant. In a long-term fertilization experiment in a Swedish pine forests where forest plots were fertilized with either $\mathrm{NH}_{4} \mathrm{NO}_{3}$ or urea, no difference in needle $\mathrm{N}$ content, $\mathrm{N}$ accumulation in the organic layer, and extractable $\mathrm{NO}_{3}{ }^{-}$in the soil solution were found (Högberg, Johannisson, \& Högberg, 2014). However, urea-fertilized plots showed a larger fractionation of ${ }^{15} \mathrm{~N}$ in needle biomass, which shows that the pathways through which $N$ becomes available are different between these two $\mathrm{N}$ sources. Du et al. (2014) performed an experiment in which $\mathrm{NH}_{4} \mathrm{NO}_{3}$ and urea were used to fertilize temperate forest soils for 2 years, showing that $\mathrm{NH}_{4} \mathrm{NO}_{3}$ inhibited soil $\mathrm{C}$ cycle processes, such as soil respiration and enzymatic activities, while urea promoted these processes. Similarly, Liu and Greaver (2010) found that fertilizer type significantly influenced several belowground responses to $\mathrm{N}$ addition, such as dissolved organic carbon, microbial biomass carbon, and soil respiration. Overall, $\mathrm{N}$ form seems to be an important factor for $\mathrm{N}$ induced changes in belowground carbon, but less so for biomass response.

TABLE 3 Response ratios for tree biomass response to nitrogen addition found in other meta-analyses

\begin{tabular}{|c|c|c|c|c|c|c|}
\hline Response parameter & $\begin{array}{l}\text { Xia and } \\
\text { Wan (2008) } \\
\text { AGBP }\end{array}$ & $\begin{array}{l}\text { Newton and } \\
\text { Amponsah (2006) } \\
\text { AGWP }\end{array}$ & $\begin{array}{l}\text { Janssens } \\
\text { et al. (2010) } \\
\text { AGBP }\end{array}$ & $\begin{array}{l}\text { Vadeboncoeur } \\
(2010) \\
\text { AGWP }\end{array}$ & $\begin{array}{l}\text { LeBauer and } \\
\text { Treseder (2008) } \\
\text { AGBP }\end{array}$ & $\begin{array}{l}\text { This study } \\
\text { AGWP }\end{array}$ \\
\hline All forest & 1.61 & & & & & $1.16(1.09-1.23)$ \\
\hline Tropical forests & & & & & $1.20(1.04-1.40)$ & $1.05(0.94-1.18)$ \\
\hline Temperate forests & & & $1.36(1.17-1.56)$ & $1.51(1.16-1.97)$ & $1.19(1.11-1.28)$ & $1.17(1.10-1.25)$ \\
\hline Boreal forests & & $1.06-1.23^{a}$ & & & & $1.20(1.08-1.33)$ \\
\hline
\end{tabular}

AGBP, aboveground biomass production; AGWP, aboveground woody biomass production.

${ }^{a}$ Represents range of means across investigated species and site qualities. 


\subsubsection{Ambient $\mathrm{N}$ deposition}

Forest stands that receive high rates of ambient $\mathrm{N}$ deposition are expected to slowly become $\mathrm{N}$ saturated and thus show a lower response to $\mathrm{N}$ addition. We did indeed find that the AGWP response to $\mathrm{N}$ addition was significantly lower at ambient $\mathrm{N}$ deposition rates above $15 \mathrm{~kg} \mathrm{~N} \mathrm{ha}^{-1} \mathrm{yr}^{-1}$ (although it should be noted here that we used model estimates of ambient $\mathrm{N}$ deposition that might not always accurately reflect actual ambient $\mathrm{N}$ deposition rates). Several previous meta-analyses confirm the importance of ambient $\mathrm{N}$ deposition when interpreting results from forest fertilization experiments. For example, Knorr et al. (2005) found that $\mathrm{N}$ addition only stimulated litter decay at plots with low levels of ambient $\mathrm{N}$ deposition, and Vadeboncoeur (2010) found some indication that NPP response to $N$ addition in north-eastern deciduous forests was lower at high $\mathrm{N}$ addition rates. Tian et al. (2016) did not find a significant effect of ambient $\mathrm{N}$ deposition level on nitrogen response efficiency, but their database might include too few observations from plots with ambient $\mathrm{N}$ deposition exceeding $15 \mathrm{~kg} \mathrm{~N} \mathrm{ha}^{-1} \mathrm{yr}^{-1}$ to detect an effect.

\subsection{Comparison of response ratios with other meta-analyses of forest $\mathrm{N}$ fertilization experiments}

This study is the first to perform a meta-analysis on $\mathrm{N}$ fertilization experiments that uses the absolute sensitivity of woody biomass to $\mathrm{N}$ addition ( $\mathrm{kg} \mathrm{C}$ per $\mathrm{kg} \mathrm{N}$ ) as response variable. As mentioned in the introduction, several other meta-analyses have previously investigated the impact of $\mathrm{N}$ addition on forest productivity (see Table S1 for an overview). However, those meta-analyses have either not focused on the AGWP response or report only relative AGWP responses rather than absolute $\mathrm{C}-\mathrm{N}$ responses.

Comparing the response ratios from our meta-analysis with results from other studies shows that our results are comparable although they are at the low end of previous estimates (Table 3). A possible explanation is that we applied more stringent criteria when selecting experiments to include in the analysis. For example, we only included observations from forest plots that were at least 10 years old, while other studies also include observations on seedlings and young trees. In general, most published studies on fertilization experiments are performed on seedlings, which means that if age is not a criterion in the selection of studies, most observations on which a meta-analysis is based will come from studies on seedlings. For example, the study by Xia and Wan (2008) contains 501 observations for $\mathrm{N}$ addition effects on tree biomass of which more than $80 \%$ comes from experiments performed on seedlings or juvenile trees. The meta-analysis by Janssens et al. (2010) contains 24 observations of $\mathrm{N}$ addition effects on tree biomass, of which half are from experiments performed on seedlings or trees younger than 3 years old. As our results show, young trees respond more strongly to $\mathrm{N}$ addition than older trees, and thus the high prevalence of experiments on seedlings in previous meta-analyses might explain the higher response found in these studies. In addition, some of the other studies include observations on forest plots that received additional treatments next to $\mathrm{N}$ addition. For example, the study by Janssens et al. (2010) includes several observations from plots that received warming and $\mathrm{CO}_{2}$ fertilization treatments along with $\mathrm{N}$ addition, and the study by Newton and Amponsah (2006) includes observations from plots that received additional micro-nutrients. This might also explain the higher responses found in these studies as compared to our study.

\subsection{Role of phosphorus}

While $\mathrm{N}$ is generally assumed to be the primary limiting nutrient in forests, enhanced $\mathrm{N}$ inputs over time may induce limitations of other nutrients, most importantly P. Observations in forests plots across Europe show that foliar $P$ concentrations are decreasing, while $N: P$ ratios are increasing (Braun et al., 2010; Jonard et al., 2015). Increasing $\mathrm{N}: \mathrm{P}$ ratios under $\mathrm{N}$ addition were also found in a meta-analysis of fertilization experiments by Yuan and Chen (2015). This study also found that next to anthropogenic $\mathrm{N}$ deposition, other global changes such as warming and drought also increase $N: P$ ratios, which might lead to an additional increase in $\mathrm{P}$ demand relative to $\mathrm{N}$ in the future. This deterioration in the $\mathrm{P}$ nutritional status is expected to limit tree response to $\mathrm{N}$ deposition and thus the capacity of forests to act as $\mathrm{C}$ sinks. $\mathrm{N}$ deposition can induce $\mathrm{P}$ limitation through two mechanisms: a) enhanced nutrient requirements to maintain growth under $\mathrm{N}$ fertilization and b) reduced investment in fine roots and mycorrhizal interactions (Jonard et al., 2015). In contrast to the increasing availabilities of $\mathrm{N}$ to ecosystems in large parts of the world through deposition, $\mathrm{P}$ is an earthbound element. Limited $\mathrm{P}$ availability will likely reduce the future forest $C$ sink, as increasing $N$ inputs are not matched by increasing $P$ inputs (Peñuelas et al., 2013).

Despite evidence for increasing $\mathrm{P}$ limitation in terrestrial systems that are subjected to long-term $\mathrm{N}$ inputs, we did not find a significant response to $\mathrm{P}$ addition in our meta-analysis. Specifically for tropical forests, this result was unexpected. We found some evidence for co-limitation of $N$ and $P$ as in several plots AGWP responded more strongly to combined $\mathrm{N}$ and $\mathrm{P}$ addition than the sum of the individual responses (Figure 4), but we have too little data to be confident about this. Another recent meta-analysis of $\mathrm{P}$ addition effects, however, found that $\mathrm{P}$ addition under ambient $\mathrm{N}$ significantly increased ANPP in tropical forests by $92 \%$ on average (Li et al., 2016). One possible explanation for this much higher response is that the study by $\mathrm{Li}$ et al. is based on many observations on seedlings and very young trees, which are expected to show a much stronger relative response to nutrient addition than mature trees.

One possible explanation for the low response to $\mathrm{P}$ addition is that the added $\mathrm{P}$ is not immediately available for plant uptake. Unlike N, P is adsorbed to soil particles and thus added $\mathrm{P}$ replenishes the soil $\mathrm{P}$ pool, but only slowly becomes available to plants over time (Shen et al., 2011). This is also shown in agricultural soils, where even in instances where $\mathrm{P}$ application rates have declined, uptake and yields continued to increase due to the continued supply 
of plant-available $\mathrm{P}$ from the residual soil $\mathrm{P}$ pool (Jungk, Claassen, Schulz, \& Wendt, 1993; Sattari, Bouwman, Giller, \& van Ittersum, 2012). This means that while often no growth response to $P$ addition is observed on the short term, $\mathrm{P}$ could significantly enhance growth over the lifespan of a forest as the added $\mathrm{P}$ slowly becomes available through adsorption/desorption. On the other hand, Markewitz, Figueiredo, de Carvalho, and Davidson (2012) found that fertilization of a secondary tropical forest with $100 \mathrm{~kg} \mathrm{P} /$ ha doubled plant available $P$ in the soil solution, indicating that at least a part of the added phosphorus is immediately available to plants.

\section{5 | Global nitrogen-induced forest carbon sequestration}

The contribution of nitrogen to global terrestrial $C$ sequestration has been debated for decades, with early estimates in the 1980s and 1990s ranging from $<100 \mathrm{Tg} \mathrm{C} /$ year up to more than $2,000 \mathrm{Tg} \mathrm{C} /$ year (Field, Chapin, Matson, \& Mooney, 1992; Hudson, Gherini, \& Goldstein, 1994; Nadelhoffer et al., 1999; Peterson \& Melillo, 1985; Schindler \& Bayley, 1993; Townsend, Braswell, Holland, \& Penner, 1996). Estimates published in the last decade show less variation and vary mostly between 220 and $720 \mathrm{Tg} \mathrm{C}$ /year sequestered in terrestrial ecosystems due to nitrogen deposition (Fleischer et al., 2015; Jain et al., 2009; Liu \& Greaver, 2009; Thomas et al., 2010; Thornton, Lamarque, Rosenbloom, \& Mahowald, 2007; de Vries et al., 2014; Zaehle et al., 2011). Our estimate cannot be compared to these estimates directly as we only assessed $\mathrm{N}$-induced $\mathrm{C}$ sequestration in the tree $\mathrm{C}$ pool through increased woody biomass accumulation, while other estimates also include $\mathrm{N}$-induced $\mathrm{C}$ sequestration in the soil $\mathrm{C}$ pool through increased litter inputs and/or reduced soil organic matter decomposition. The soil $\mathrm{C}-\mathrm{N}$ response is determined by $\mathrm{N}$-induced changes in $\mathrm{C}$ input by litterfall and the $\mathrm{N}$-induced changes in $C$ losses from respiration (see Figure 1). Several metaanalyses have found that $\mathrm{N}$ addition reduces forest soil respiration and increases soil C sequestration (Janssens et al., 2010; Nave et al., 2009; Zhou et al., 2014), others found no effect of $\mathrm{N}$ on soil respiration but an increase in aboveground litter inputs (Liu \& Greaver, 2010). Several mechanisms through which $N$ affects soil respiration have been proposed, such as an increase in litter quality, decrease in belowground $\mathrm{C}$ allocation, shifts in microbial community composition, alterations in mycorrhizal interactions, and SOM stabilization following $\mathrm{N}$ addition (see e.g., Janssens et al., 2010 for an overview).

Table 4 presents the published estimates of the global $\mathrm{N}$-induced forest $\mathrm{C}$ sink split up into the contributions of the tree (vegetation) and soil $\mathrm{C}$ sinks. While estimates of the magnitude of the total $\mathrm{N}$ induced forest $C$ sink vary between 97 and $740 \mathrm{Tg} \mathrm{C}$ /year, the relative contribution of soil $\mathrm{C}$ sequestration to total $\mathrm{N}$-induced $\mathrm{C}$ sequestration is rather constant between 38 and $50 \%$. Stoichiometric scaling studies have estimated that the soil accounts for $43-47 \%$ of the additional $\mathrm{N}$-induced $\mathrm{C}$ sequestration (Peterson \& Melillo, 1985; Nadelhoffer et al., 1999; de Vries et al., 2014; see Table 4). These studies generally assume that $50-70 \%$ of the deposited $\mathrm{N}$ is allocated to the soil (vs. only $5-8 \%$ to woody biomass); however, the soil C:N ratio (ca. 20:1-30:1) is much lower than the woody biomass C:N ratio (ca. 150:1-500:1). Estimates of global $\mathrm{N}$-induced $\mathrm{C}$ sequestration derived by DGVMs vary between 260 and $740 \mathrm{Tg} C$ per year (Townsend et al., 1996; Jain et al., 2009; Fleischer et al., 2015; see Table 4). Also here, the soil accounts for about $38-50 \%$ of the total $\mathrm{N}$-induced $\mathrm{C}$ sequestration, with the exception of Townsend et al. (1996), where the soil only contributes $18 \%$. A long-term fertilization experiment in a boreal forest found that about $38 \%$ of the $\mathrm{N}$ induced $C$ sequestration effect is due to enhanced $C$ soil organic

TABLE 4 Overview of published estimates of nitrogen-induced forest carbon sequestration ( $\mathrm{Tg}$ C/year). Only estimates that specify the individual contributions of vegetation and soil to total nitrogen-induced carbon sequestration are listed. The last row shows the relative contribution of the soil to total $\mathrm{N}$-induced $\mathrm{C}$ sequestration

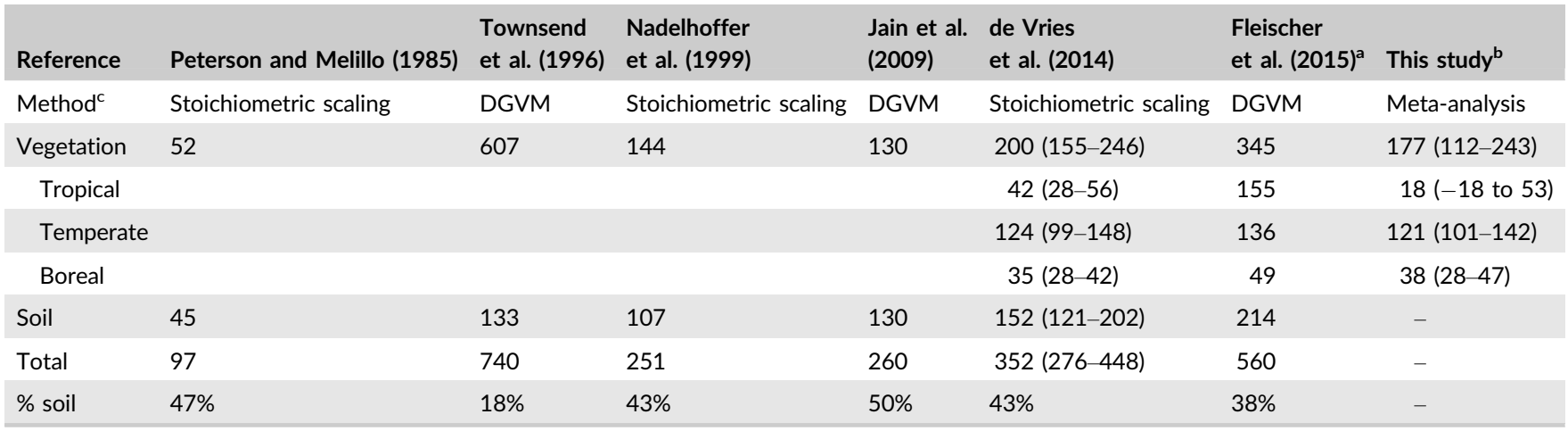

DGVM, dynamic global vegetation model.

${ }^{a}$ Estimates from the global-scale simulations.

${ }^{b}$ Estimate includes aboveground woody biomass presented in Table 1 multiplied by a factor 1.2 to account for additional $\mathrm{N}$-induced carbon sequestration in belowground woody biomass, see Table S3.

${ }^{\mathrm{C}}$ Estimates presented in this table do not only vary due to differences in methodologies and $\mathrm{C}-\mathrm{N}$ response ratios, but also due to differences in the underlying $\mathrm{N}$ deposition estimates. For all estimates, $\mathrm{N}$ deposition refers to total (natural + anthropogenic) $\mathrm{N}$ deposition. Duce et al. (2008) estimated that $77 \%$ of the $\mathrm{N}$ deposited on land comes from anthropogenic sources. Multiplying our estimate with this fraction, we estimated that carbon sequestration in woody biomass induced by anthropogenic $\mathrm{N}$ deposition is about $136 \mathrm{Tg} \mathrm{C} /$ year (114 Tg C/year in aboveground woody biomass). 
horizon (Gundale et al., 2014; Maaroufi et al., 2015). A similar experiment at four temperate forest sites found that the soil accounted for $58 \%$ of $\mathrm{N}$-induced $\mathrm{C}$ sequestration on average, with large variations between the four sites in the study (14-77\%) (Pregitzer et al., 2008). A recent meta-analysis also concluded that the size of the $N$ induced $C$ sequestration effect in the soil is equivalent in magnitude to the effect of $\mathrm{N}$ deposition on tree $\mathrm{C}$ sequestration (Janssens et al., 2010).

Our estimate for total $\mathrm{N}$-induced $\mathrm{C}$ sequestration in trees' woody biomass of 177 (112-243) Tg C/year is slightly higher than estimates by Nadelhoffer et al. (1999) and Jain et al. (2009), slightly lower than recent estimates by de Vries et al. (2014), and about half of the estimate by the DGVM of Fleischer et al. (2015). Notably, the difference with the estimate from Fleischer et al. is mainly because their model predicted that $\mathrm{N}$ deposition greatly enhances $\mathrm{C}$ sequestration in tropical forests, while we found no evidence for a response of the tree $\mathrm{C}$ pool to $\mathrm{N}$ addition in tropical forests. Based on our results, we conclude that DGVMs likely overestimate $\mathrm{N}$-induced $\mathrm{C}$ sequestration in the tropics.

\subsection{Considerations for upscaling $\mathrm{C}-\mathrm{N}$ responses to estimate global nitrogen-induced forest carbon sequestration}

We used average $\mathrm{C}-\mathrm{N}$ responses per biome to scale-up our estimates of $\mathrm{N}$-induced $\mathrm{C}$ sequestration based on plot-level observations to the global scale, in line with previous studies (Nadelhoffer et al., 1999; Thomas et al., 2010; de Vries et al., 2014). However, our meta-analysis revealed that factors other than biome, such as forest productivity, stand age, and $\mathrm{N}$ addition rate, also affect the $\mathrm{C}-\mathrm{N}$ response. For some of these variables, it is not possible to use them in upscaling. The decline in forest $\mathrm{C}-\mathrm{N}$ response with increasing rates of $\mathrm{N}$ addition, for example, cannot be reflected in an upscaling approach, as $\mathrm{N}$ deposition rates that forests currently experience almost all fall into the lowest rate used in $\mathrm{N}$ addition experiments most forest plots in our database receive somewhere between 2 and $35 \mathrm{~kg} \mathrm{~N} \mathrm{ha}^{-1} \mathrm{yr}^{-1}$ (mean: $5.4 \mathrm{~kg} \mathrm{~N} \mathrm{ha}^{-1} \mathrm{yr}^{-1}$ ), whereas experimental $\mathrm{N}$ additions rates in our database varied between 30 and $300 \mathrm{~kg}$ $\mathrm{N} \mathrm{ha}^{-1} \mathrm{yr}^{-1}$ (mean: $71 \mathrm{~kg} \mathrm{~N}^{-1} \mathrm{yr}^{-1}$ ). The difference in response to $\mathrm{N}$ addition between young and old forest stands can also not be used for upscaling $\mathrm{C}-\mathrm{N}$ responses, as there are currently no global maps of forest stand age (although there are data available at the continental scale, e.g., for North American forests Pan, Chen, et al., 2011).

If there had been clear correlations between the climate zone (biome) and other determinants of forests' response to $\mathrm{N}$ addition, this might have affected the upscaling procedures as it would have influenced the observed differences in AGWP response between the climate zones. For example, climate zone might be correlated with stand age (tropical and boreal forests might be older than temperate forests) and ambient $\mathrm{N}$ deposition rate (temperate forests might receive higher rates of ambient $\mathrm{N}$ deposition than boreal and tropical forests). It was not the aim of this paper to disentangle all possible interactions between variables, but we did check for correlations (see Table S7). Results showed that boreal forest plots in our database on average had a lower productivity and received lower experimental $\mathrm{N}$ addition rates than temperate and tropical forest plots. This will have affected the higher $\mathrm{C}-\mathrm{N}$ response of boreal forests. For productivity, it is plausible to assume that the differences between experimental plots reflect actual differences in the field, which makes upscaling based on climate zones an adequate first rough approach. However, for experimental $\mathrm{N}$ addition rate, differences between climate zones do not reflect real-life variation and thus this effect of cannot be adequately reflected in an upscaling approach. The decrease in $\mathrm{C}-\mathrm{N}$ response with increasing $\mathrm{N}$ inputs that we found also implies that $\mathrm{C}-\mathrm{N}$ responses in temperate and tropical forests might have been underestimated, as experimental $\mathrm{N}$ addition rates for these biomes received vastly exceeded typical ambient $\mathrm{N}$ deposition rates. In addition, we found that average $\mathrm{N}$ deposition in boreal forest plots in our database $\left(7.8 \mathrm{~kg} \mathrm{~N} \mathrm{ha}^{-1} \mathrm{yr}^{-1}\right.$, see Table S7) was much higher than the model-derived average for all boreal forests (1.8 $\mathrm{kg} \mathrm{N} \mathrm{ha}^{-1} \mathrm{yr}^{-1}$, see Table 1). Given the decline in $\mathrm{C}-\mathrm{N}$ response with increasing levels of ambient $\mathrm{N}$ deposition, this might mean that the $\mathrm{C}-\mathrm{N}$ response for boreal forests that we derived is an underestimation.

Another caveat when upscaling results from fertilization experiments is that responses at very low rates of $\mathrm{N}$ addition might be lower than mean response rates from experiments suggest. Previous studies show that forests hardly respond to $\mathrm{N}$ deposition at levels below approximately $3-5 \mathrm{~kg} \mathrm{~N}$ ha $^{-1} \mathrm{yr}^{-1}$ because of microbial competition with plant (tree) uptake (Kaye \& Hart, 1997) and reduced biological $\mathrm{N}$ fixation due to enhanced $\mathrm{N}$ deposition (Gundale, Deluca, \& Nordin, 2011). This might have led to an overestimation of the global $\mathrm{N}$-induced $\mathrm{C}$ sink in boreal forests, where ambient $\mathrm{N}$ deposition rates are low. On the other hand, response rates may be underestimated in the range from 3-5 up to $10-15 \mathrm{~kg} \mathrm{~N} \mathrm{ha}^{-1} \mathrm{yr}^{-1}$ where $\mathrm{N}$ deposition may stimulate growth quite strongly (e.g., Thomas et al., 2010). Overall, it is not clear whether use of a mean $\mathrm{C}-\mathrm{N}$ response over the whole $\mathrm{N}$ deposition range leads to an overestimation or underestimation of the $\mathrm{N}$ deposition impact on global forest C sequestration.

While this study has focused on $\mathrm{C}-\mathrm{N}$ responses in (aboveground) biomass, soils also account for a substantial share of the $\mathrm{N}$-induced $\mathrm{C}$ sequestration response. While several studies have estimated $\mathrm{N}$ induced soil $\mathrm{C}$ sequestration (see e.g., Table S1 and Table 4), disentangling the various mechanisms through which $\mathrm{N}$ affects soil biologic processes is still a puzzle that needs to be solved to improve predictions of future $\mathrm{N}$-induced soil $\mathrm{C}$ sequestration. Improving estimates of global $\mathrm{N}$-induced forest $\mathrm{C}$ sequestration from empirical data furthermore requires more quantitative insight in the factors affecting forests' response to $\mathrm{N}$ addition at different $\mathrm{N}$ input levels. This includes factors related to site fertility, such as nutrient concentrations and/or ratios in foliage and soil (e.g., Fernández-Martínez et al., 2014), climatic factors, such as temperature (e.g., Sigurdsson, Medhurst, Wallin, Eggertsson, \& Linder, 2013) and precipitation (e.g., Lim et al., 2015), as well as variations in $\mathrm{C}-\mathrm{N}$ responses between 
tree species in view of different symbiotic relations with mycorrhizal fungi (e.g., Averill, Turner, \& Finzi, 2014; Chalot \& Brun, 1998; Thomas et al., 2010). Scaling up plot-level results to the global scale also depends on the availability of global datasets with information on factors governing $\mathrm{C}-\mathrm{N}$ responses.

\section{ACKNOWLEDGMENTS}

Lena Schulte-Uebbing acknowledges funding of this research by the NWO (project number 022.003.009), provided by a project initiated by the SENSE Research School. We acknowledge Hein Tanis for help with data collection, Frank Dentener for sending global spatially explicit nitrogen deposition estimates, and Jan Cees Voogd for help with the overlay of nitrogen deposition data and land use maps. Finally, we are grateful to Douglas B. Mainwaring, Houbao Fan, Jean-David Moore, Jouni Kilpeläinen, David Coyle, Joshua B. Fisher, Jürgen Homeier, Anna Saarsalmi, Staffan Jacobson, Rachhpal Jassal, Adrian Ares, Julio Campo Alves, Daniela F. Cusack, Edmund V.J. Tanner, and S. Joseph Wright for providing data on fertilization experiments additional to published results.

\section{ORCID}

Lena Schulte-Uebbing (iD http://orcid.org/0000-0002-5511-1432

\section{REFERENCES}

Averill, C., Turner, B. L., \& Finzi, A. C. (2014). Mycorrhiza-mediated competition between plants and decomposers drives soil carbon storage. Nature, 505, 543-545.

Bala, G., Devaraju, N., Chaturvedi, R. K., Caldeira, K., \& Nemani, R. (2013). Nitrogen deposition: How important is it for global terrestrial carbon uptake. Biogeosciences, 10, 7147-7160.

Borenstein, M., Hedges, L. V., Higgins, J. P., \& Rothstein, H. R. (2009). Introduction to meta-analysis. West Sussex, UK: John Wiley \& Sons.

Braun, S., Thomas, V. F. D., Quiring, R., \& Flückiger, W. (2010). Does nitrogen deposition increase forest production? The role of phosphorus. Environmental Pollution, 158, 2043-2052.

Chalot, M., \& Brun, A. (1998). Physiology of organic nitrogen acquisition by ectomycorrhizal fungi and ectomycorrhizas. FEMS Microbiology Reviews, 22, 21-44.

Ciais, P., Schelhaas, M. J., Zaehle, S., Piao, S. L., Cescatti, A., Liski, J., .. Nabuurs, G. J. (2008). Carbon accumulation in European forests. Nature Geoscience, 1, 425-429.

Cleveland, C. C., Houlton, B. Z., Smith, W. K., Marklein, A. R., Reed, S. C., Parton, W., ... Running, S. W. (2013). Patterns of new versus recycled primary production in the terrestrial biosphere. Proceedings of the National Academy of Sciences of the United States of America, 110, 12733-12737.

Dentener, F., Drevet, J., Lamarque, J. F., Bey, I., Eickhout, B., Fiore, A. M., ... Wild, O. (2006). Nitrogen and sulfur deposition on regional and global scales: A multimodel evaluation. Global Biogeochemical Cycles, 20, GB4003.

Du, Y., Guo, P., Liu, J., Wang, C., Yang, N., \& Jiao, Z. (2014). Different types of nitrogen deposition show variable effects on the soil carbon cycle process of temperate forests. Global Change Biology, 20, 32223228.
Duce, R. A., LaRoche, J., Altieri, K., Arrigo, K. R., Baker, A. R., Capone, D. G., ... Zamora, L. (2008). Impacts of atmospheric anthropogenic nitrogen on the open ocean. Science, 320 (5878), 893-897.

Elser, J. J., Bracken, M. E. S., Cleland, E. E., Gruner, D. S., Harpole, W. S., Hillebrand, H., ... Smith, J. E. (2007). Global analysis of nitrogen and phosphorus limitation of primary producers in freshwater, marine and terrestrial ecosystems. Ecology Letters, 10, 1135-1142.

Fang, Y., Zhu, W., Gundersen, P., Mo, J., Zhou, G., \& Yoh, M. (2009). Large loss of dissolved organic nitrogen from nitrogen-saturated forests in subtropical China. Ecosystems, 12, 33-45.

FAO (2016).Global Forest Resources Assessment 2015. Rome, 44 pp.

Fernández-Martínez, M., Vicca, S., Janssens, I. A., Sardans, J., Luyssaert, S., Campioli, M., ... Peñuelas, J. (2014). Nutrient availability as the key regulator of global forest carbon balance. Nature Climate Change, 4, 471-476.

Field, C. B., Chapin, F. S. III, Matson, P. A., \& Mooney, H. A. (1992). Responses of terrestrial ecosystems to the changing atmosphere: A resource-based approach. Annual Review of Ecology and Systematics, 23, 201-235.

Fleischer, K., Rebel, K. T., van der Molen, M. K., Erisman, J. W., Wassen, M. J., van Loon, E. E., .. Dolman, A. J. (2013). The contribution of nitrogen deposition to the photosynthetic capacity of forests. Global Biogeochemical Cycles, 27, 187-199.

Fleischer, K., Wårlind, D., van der Molen, M., Rebel, K., Arneth, A., Erisman, J. W., ... Dolman, A. J. (2015). Low historical nitrogen deposition effect on carbon sequestration in the boreal zone. Journal of Geophysical Research: Biogeosciences, 120, 2542-2561.

Fowler, D., Coyle, M., Skiba, U., Sutton, M. A., Cape, J. N., Reis, S., ... Voss, M. (2013). The global nitrogen cycle in the twenty-first century. Philosophical Transactions of the Royal Society of London. Series B, Biological Sciences, 368, 20130164

Galloway, J. N., Townsend, A. R., Erisman, J. W., Bekunda, M., Cai, Z., Freney, J. R., ... Sutton, M. A. (2008). Transformation of the nitrogen cycle: Recent trends, questions, and potential solutions. Science, 320, 889-892.

GLC (2003). The Global Land Cover Map for the Year 2000. GLC2000 database, European Commision Joint Research Centre (JRC), Retrieved from: http://www-gem.jrc.it/glc2000.

Gundale, M. J., Deluca, T. H., \& Nordin, A. (2011). Bryophytes attenuate anthropogenic nitrogen inputs in boreal forests. Global Change Biology, 17, 2743-2753.

Gundale, M. J., From, F., Bach, L. H., \& Nordin, A. (2014). Anthropogenic nitrogen deposition in boreal forests has a minor impact on the global carbon cycle. Global Change Biology, 20, 276-286.

Hedges, L. V., Gurevitch, J., \& Curtis, P. S. (1999). The meta-analysis of response ratios in experimental ecology. Ecology, 80, 11501156.

Högberg, P., Fan, H., Quist, M., Binkley, D., \& Tamm, C. O. (2006). Tree growth and soil acidification in response to 30 years of experimental nitrogen loading on boreal forest. Global Change Biology, 12, 489499.

Högberg, P., Johannisson, C., \& Högberg, M. N. (2014). Is the high ${ }^{15} \mathrm{~N}$ natural abundance of trees in $\mathrm{N}$-loaded forests caused by an internal ecosystem $\mathrm{N}$ isotope redistribution or a change in the ecosystem $\mathrm{N}$ isotope mass balance? Biogeochemistry, 117, 351-358.

Hudson, R. J. M., Gherini, S. A., \& Goldstein, R. A. (1994). Modeling the global carbon cycle: Nitrogen fertilization of the terrestrial biosphere and the "missing" $\mathrm{CO}_{2}$ sink. Global Biogeochemical Cycles, 8, 307-333.

Hyvönen, R., Persson, T., Andersson, S., Olsson, B., Ågren, G. I., \& Linder, S. (2008). Impact of long-term nitrogen addition on carbon stocks in trees and soils in northern Europe. Biogeochemistry, 89, 121-137.

livonen, S., Kaakinen, S., Jolkkonen, A., Vapaavuori, E., \& Linder, S. (2006). Influence of long-term nutrient optimization on biomass, 
carbon, and nitrogen acquisition and allocation in Norway spruce. Canadian Journal of Forest Research, 36, 1563-1571.

Jain, A., Yang, X., Kheshgi, H., McGuire, A. D., Post, W., \& Kicklighter, D. (2009). Nitrogen attenuation of terrestrial carbon cycle response to global environmental factors. Global Biogeochemical Cycles, 23, GB4028.

Janssens, I. A., Dieleman, W., Luyssaert, S., Subke, J.-A., Reichstein, M., Ceulemans, R., ... Law, B. E. (2010). Reduction of forest soil respiration in response to nitrogen deposition. Nature Geoscience, 3, 315322.

Janssens, I. A., Freibauer, A., Ciais, P., Smith, P., Nabuurs, G.-J., Folberth, G., ... Dolman, A. J. (2003). Europe's terrestrial biosphere absorbs 7 to $12 \%$ of European anthropogenic $\mathrm{CO}_{2}$ emissions. Science, 300, 1538-1542.

Jonard, M., Fürst, A., Verstraeten, A., Thimonier, A., Timmermann, V., Potočić, N., ... Rautio, P. (2015). Tree mineral nutrition is deteriorating in Europe. Global Change Biology, 21, 418-430.

Jungk, A., Claassen, N., Schulz, V., \& Wendt, J. (1993). Availability of phosphate reserves in arable soils. Zeitschrift für Pflanzenernährung und Bodenkunde, 156, 397-406.

Kaye, J. P., \& Hart, S. C. (1997). Competition for nitrogen between plants and soil microorganisms. Trends in Ecology and Evolution, 12, 139143.

Knorr, M., Frey, S. D., \& Curtis, P. S. (2005). Nitrogen additions and litter decomposition: A meta-analysis. Ecology, 86, 3252-3257.

Laubhann, D., Sterba, H., Reinds, G. J., \& de Vries, W. (2009). The impact of atmospheric deposition and climate on forest growth in European monitoring plots: An individual tree growth model. Forest Ecology and Management, 258, 1751-1761.

Le Quéré, C., Moriarty, R., Andrew, R. M., Canadell, J. G., Sitch, S., Korsbakken, J. I., ... Zeng, N. (2015). Global carbon budget 2015. Earth System Science Data, 7, 349-396.

LeBauer, D. S., \& Treseder, K. K. (2008). Nitrogen limitation of net primary productivity in terrestrial ecosystems is globally distributed. Ecology, 89, 371-379.

Li, Y., Niu, S., \& Yu, G. (2016). Aggravated phosphorus limitation on biomass production under increasing nitrogen loading: A meta-analysis. Global Change Biology, 22, 934-943.

Lim, H., Oren, R., Palmroth, S., Tor-ngern, P., Mörling, T., Näsholm, T., ... Linder, S. (2015). Inter-annual variability of precipitation constrains the production response of boreal Pinus sylvestris to nitrogen fertilization. Forest Ecology and Management, 348, 31-45.

Liu, L., \& Greaver, T. L. (2009). A review of nitrogen enrichment effects on three biogenic GHGs: The $\mathrm{CO}_{2}$ sink may be largely offset by stimulated $\mathrm{N} 2 \mathrm{O}$ and $\mathrm{CH} 4$ emission. Ecology Letters, 12, 1103-1117.

Liu, L., \& Greaver, T. L. (2010). A global perspective on belowground carbon dynamics under nitrogen enrichment. Ecology Letters, 13, 819-828.

Liu, J. X., Zhou, G. Y., Zhang, D. Q., Xu, Z. H., Duan, H. L., Deng, Q., \& Zhao, L. (2010). Carbon dynamics in subtropical forest soil: Effects of atmospheric carbon dioxide enrichment and nitrogen addition. Journal of Soils and Sediments, 10, 730-738.

Lovett, G. M., Arthur, M. A., Weathers, K. C., Fitzhugh, R. D., \& Templer, P. H. (2013). Nitrogen addition increases carbon storage in soils, but not in trees, in an Eastern U.S. deciduous forest. Ecosystems, 16, 980-1001.

Lu, X., Mao, Q., Gilliam, F. S., Luo, Y., \& Mo, J. (2014). Nitrogen deposition contributes to soil acidification in tropical ecosystems. Global Change Biology, 20, 3790-3801.

Lu, M., Zhou, X., Luo, Y., Yang, Y., Fang, C., Chen, J., \& Li, B. (2011). Minor stimulation of soil carbon storage by nitrogen addition: $A$ meta-analysis. Agriculture, Ecosystems and Environment, 140, 234-244.

Luyssaert, S., Inglima, I., Jung, M., Richardson, A. D., Reichstein, M., Papa, D., ... Janssens, I. A. (2007). $\mathrm{CO}_{2}$ balance of boreal, temperate, and tropical forests derived from a global database. Global Change Biology, 13, 2509-2537.
Maaroufi, N. I., Nordin, A., Hasselquist, N. J., Bach, L. H., Palmqvist, K., \& Gundale, M. J. (2015). Anthropogenic nitrogen deposition enhances carbon sequestration in boreal soils. Global Change Biology, 21, 31693180.

Magill, A. H., Aber, J. D., Currie, W. S., Nadelhoffer, K. J., Martin, M. E., McDowell, W. H., ... Steudler, P. (2004). Ecosystem response to 15 years of chronic nitrogen additions at the Harvard Forest LTER, Massachusetts, USA. Forest Ecology and Management, 196, 7-28.

Magnani, F., Mencuccini, M., Borghetti, M., Berbigier, P., Berninger, F., Delzon, S., ... Grace, J. (2007). The human footprint in the carbon cycle of temperate and boreal forests. Nature, 447, 848-850.

Markewitz, D., Figueiredo, R. O., de Carvalho, C. J. R., \& Davidson, E. A. (2012). Soil and tree response to $P$ fertilization in a secondary tropical forest supported by an Oxisol. Biology and Fertility of Soils, 48 , 665-678.

Maynard, D. G., Paré, D., Thiffault, E., Lafleur, B., Hogg, K. E., \& Kishchuk, B. (2014). How do natural disturbances and human activities affect soils and tree nutrition and growth in the Canadian boreal forest? Environmental Reviews, 22, 161-178.

Myneni, R. B., Dong, J., Tucker, C. J., Kaufmann, R. K., Kauppi, P. E., Liski, J., ... Hughes, M. K. (2001). A large carbon sink in the woody biomass of Northern forests. Proceedings of the National Academy of Sciences of the United States of America, 98, 14784-14789.

Nabuurs, G.-J., Lindner, M., Verkerk, P. J., Gunia, K., Deda, P., Michalak, R., \& Grassi, G. (2013). First signs of carbon sink saturation in European forest biomass. Nature Climate Change, 3, 792-796.

Nabuurs, G.-J., Schelhaas, M.-J., \& Field, C. B. (2003). Temporal evolution of the European forest sector carbon sink from 1950 to 1999. Global Change Biology, 9, 152-160.

Nadelhoffer, K. J., Emmett, B. A., Gundersen, P., Kjønaas, O. J., Koopmans, C. J., Schleppi, P., ... Wright, R. F. (1999). Nitrogen deposition makes a minor contribution to carbon sequestration in temperate forests. Nature, 398, 145-148.

Nave, L. E., Vance, E. D., Swanston, C. W., \& Curtis, P. S. (2009). Impacts of elevated $\mathrm{N}$ inputs on north temperate forest soil $\mathrm{C}$ storage, $\mathrm{C} / \mathrm{N}$, and net N-mineralization. Geoderma, 153, 231-240.

Newton, P. F., \& Amponsah, I. G. (2006). Systematic review of short-term growth responses of semi-mature black spruce and jack pine stands to nitrogen-based fertilization treatments. Forest Ecology and Management, 237, 1-14.

Olson, D. M., Dinerstein, E., Wikramanayake, E. D., Burgess, N. D., Powell, G. V. N., Underwood, E. C., ... Kassem, K. R. (2001). Terrestrial ecoregions of the world: A new map of life on Earth. BioScience, 51, 933.

Pan, Y., Birdsey, R. A., Fang, J., Houghton, R., Kauppi, P. E., Kurz, W. A., ... Hayes, D. (2011). A large and persistent carbon sink in the world's forests. Science, 333, 988-993.

Pan, Y., Chen, J. M., Birdsey, R., McCullough, K., He, L., \& Deng, F. (2011). Age structure and disturbance legacy of North American forests. Biogeosciences, 8, 715-732.

Peñuelas, J., Poulter, B., Sardans, J., Ciais, P., van der Velde, M., Bopp, L., ... Janssens, I. A. (2013). Human-induced nitrogen-phosphorus imbalances alter natural and managed ecosystems across the globe. Nature Communications, 4, 2934.

Peterson, B. J., \& Melillo, J. M. (1985). The potential storage of carbon caused by eutrophication of the biosphere. Tellus Series B, 37, 117127.

Pregitzer, K. S., Burton, A. J., Zak, D. R., \& Talhelm, A. F. (2008). Simulated chronic nitrogen deposition increases carbon storage in Northern Temperate forests. Global Change Biology, 14, 142-153.

Pregitzer, K. S., \& Euskirchen, E. S. (2004). Carbon cycling and storage in world forests: Biome patterns related to forest age. Global Change Biology, 10, 2052-2077.

R Core Team (2015). R: A Language and environment for statistical computing. 
Sattari, S. Z., Bouwman, A. F., Giller, K. E., \& van Ittersum, M. K. (2012). Residual soil phosphorus as the missing piece in the global phosphorus crisis puzzle. Proceedings of the National Academy of Sciences, 109, 6348-6353.

Schindler, D. W., \& Bayley, S. E. (1993). The biosphere as an increasing sink for atmospheric carbon: Estimates from increased nitrogen depostion. Global Biogeochemical Cycles, 7, 717-733.

Shen, G., Moore, J. A., \& Hatch, C. R. (2001). The effect of nitrogen fertilization, rock type, and habitat type on individual tree mortality. Forest Science, 47, 203-213.

Shen, J., Yuan, L., Zhang, J., Li, H., Bai, Z., Chen, X., ... Zhang, F. (2011). Phosphorus dynamics: From soil to plant. Plant Physiology, 156, $997-$ 1005.

Shryock, B., Littke, K., Ciol, M., Briggs, D., \& Harrison, R. (2014). The effects of urea fertilization on carbon sequestration in Douglas-fir plantations of the coastal Pacific Northwest. Forest Ecology and Management, 318, 341-348.

Sigurdsson, B. D., Medhurst, J. L., Wallin, G., Eggertsson, O., \& Linder, S. (2013). Growth of mature boreal Norway spruce was not affected by elevated $[\mathrm{CO}(2)]$ and/or air temperature unless nutrient availability was improved. Tree Physiology, 33, 1192-1205.

Sitch, S., Friedlingstein, P., Gruber, N., Jones, S. D., Murray-Tortarolo, G. Ahlström, A., ... Myneni, R. (2015). Recent trends and drivers of regional sources and sinks of carbon dioxide. Biogeosciences, 12, 653-679.

Solberg, S., Dobbertin, M., Reinds, G. J., Lange, H., Andreassen, K., Fernandez, P. G., ... de Vries, W. (2009). Analyses of the impact of changes in atmospheric deposition and climate on forest growth in European monitoring plots: A stand growth approach. Forest Ecology and Management, 258, 1735-1750.

Sun, Z., Liu, L., Peng, S., Peñuelas, J., Zeng, H., \& Piao, S. (2016). Agerelated modulation of the nitrogen resorption efficiency response to growth requirements and soil nitrogen availability in a temperate pine plantation. Ecosystems, 19, 698-709.

Sutton, M. A., Simpson, D., Levy, P. E., Smith, R. I., Reis, S., van Oijen, M., \& de Vries, W. (2008). Uncertainties in the relationship between atmospheric nitrogen deposition and forest carbon sequestration. Global Change Biology, 14, 2057-2063.

Tanner, E. V. J., Kapos, V., Freskos, S., Healey, J. R., \& Theobald, A. M. (1990). Nitrogen and phosphorus fertilization of Jamaican montane forest trees. Journal of Tropical Ecology, 6, 231-238.

Templer, P. H., Mack, M. C., Chapin III, F. S., Christenson, L. M., Compton, J. E., Crook, H. D., ... Zak, D. R. (2012). Sinks for nitrogen inputs in terrestrial ecosystems: A meta-analysis of $15 \mathrm{~N}$ tracer field studies. Ecology, 93, 1816-1829.

Thomas, R. Q., Canham, C. D., Weathers, K. C., \& Goodale, C. L. (2010). Increased tree carbon storage in response to nitrogen deposition in the US. Nature Geoscience, 3, 13-17.

Thornton, P. E., Lamarque, J.-F., Rosenbloom, N. A., \& Mahowald, N. M. (2007). Influence of carbon-nitrogen cycle coupling on land mode response to $\mathrm{CO}_{2}$ fertilization and climate variability. Global Biogeochemical Cycles, 21, GB4018.

Tian, D., Wang, H., Sun, J., \& Niu, S. (2016). Global evidence on nitrogen saturation of terrestrial ecosystem net primary productivity. Environmental Research Letters, 11, 24012.

Townsend, A. R., Braswell, B. H., Holland, E. A., \& Penner, J. E. (1996). Spatial and temporal patterns in terrestrial carbon storage due to deposition of fossil fuel nitrogen. Ecological Applications, 6, 806-814.
Vadeboncoeur, M. A. (2010). Meta-analysis of fertilization experiments indicates multiple limiting nutrients in northeastern deciduous forests. Canadian Journal of Forest Research, 40, 1766-1780.

Viechtbauer, W. (2010). Conducting meta-analyses in $R$ with the metafor package. Journal of Statistical Software, 36, 1-48.

Vitousek, P. P. M., Aber, J. J. D., Howarth, R. W., Likens, G. E., Matson, P. A., Schindler, D. W., ... Tilman, D. G. (1997). Human alteration of the global nitrogen cycle: Sources and consequences. Ecological Applications, 7, 737-750.

Vitousek, P. M., Walker, L. R., Whiteaker, L. D., \& Matson, P. A. (1993). Nutrient limitations to plant growth during primary succession in Hawaii Volcanoes National Park. Biogeochemistry, 23, 197-215.

de Vries, W., Du, E., \& Butterbach-Bahl, K. (2014). Short and long-term impacts of nitrogen deposition on carbon sequestration by forest ecosystems. Current Opinion in Environmental Sustainability, 9-10, 90 104.

de Vries, W., Solberg, S., Dobbertin, M., Sterba, H., Laubhahn, D., Reinds, G. J., ... Sutton, M. A. (2008). Ecologically implausible carbon response? Nature, 451, E1-E3.

Wieder, W. R., Allison, S. D., Davidson, E. A., Georgiou, K., Hararuk, O., $\mathrm{He}, \mathrm{Y} ., \ldots \mathrm{Xu}, \mathrm{X}$. (2015). Explicitly representing soil microbial processes in Earth system models. Global Biogeochemical Cycles, 29, 1782-1800.

Xia, J., \& Wan, S. (2008). Global response patterns of terrestrial plant species to nitrogen addition. The New Phytologist, 179, 428439.

Yuan, Z. Y., \& Chen, H. Y. H. (2015). Decoupling of nitrogen and phosphorus in terrestrial plants associated with global changes. Nature Climate Change, 5, 465-469.

Zaehle, S. (2013). Terrestrial nitrogen-carbon cycle interactions at the global scale. Philosophical Transactions of the Royal Society B: Biological Sciences, 368, 20130125.

Zaehle, S., Ciais, P., Friend, A. D., \& Prieur, V. (2011). Carbon benefits of anthropogenic reactive nitrogen offset by nitrous oxide emissions. Nature Geoscience, 4, 601-605.

Zhou, L., Zhou, X., Zhang, B., Lu, M., Luo, Y., Liu, L., \& Li, B. (2014). Different responses of soil respiration and its components to nitrogen addition among biomes: A meta-analysis. Global Change Biology, 20, 2332-2343.

\section{SUPPORTING INFORMATION}

Additional Supporting Information may be found online in the supporting information tab for this article.

How to cite this article: Schulte-Uebbing L, de Vries W. Global-scale impacts of nitrogen deposition on tree carbon sequestration in tropical, temperate, and boreal forests: $A$ meta-analysis. Glob Change Biol. 2018;24:e416-e431. https://doi.org/10.1111/gcb.13862 